Article

\title{
Sentinel-1 DInSAR for Monitoring Active Landslides in Critical Infrastructures: The Case of the Rules Reservoir (Southern Spain)
}

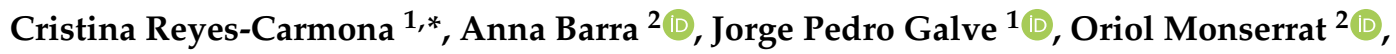 \\ José Vicente Pérez-Peña ${ }^{1,3}$, Rosa María Mateos ${ }^{4}$, Davide Notti ${ }^{5}$ (D), Patricia Ruano ${ }^{1,6}{ }^{(D)}$, \\ Agustín Millares ${ }^{7}$ D, Juan López-Vinielles ${ }^{4,8}$ and José Miguel Azañón 1,6 \\ 1 Departamento de Geodinámica, Universidad de Granada, Avenida del Hospicio s/n, 18010 Granada, Spain; \\ jpgalve@ugr.es (J.P.G.); vperez@ugr.es (J.V.P.-P.); pruano@ugr.es (P.R.); jazanon@ugr.es (J.M.A.) \\ 2 Geomatics Division, Centre Tecnològic de Telecomunicacions de Catalunya (CTTC), Avinguda Carl \\ Friedrich Gauss 7, 08860 Castelldefels, Spain; anna.barra@cttc.cat (A.B.); omonserrat@cttc.cat (O.M.) \\ 3 Instituto Andaluz de Geofísica, Calle del Profesor Clavera 12, 18071 Granada, Spain \\ 4 Geohazards InSAR Laboratory and Modelling Group (InSARlab), Geoscience Research Department, \\ Geological Survey of Spain (IGME), Calle de Ríos Rosas 23, 28003 Madrid, Spain; \\ rm.mateos@igme.es (R.M.M.); jlvinielles@hemav.com (J.L.-V.) \\ 5 Italian National Research Council, Research Institute for Geo-Hydrological Protection (CNR-IRPI), \\ Strada delle Cacce 73, 10135 Torino, Italy; davide.notti@irpi.cnr.it \\ 6 Instituto Andaluz de Ciencias de la Tierra (IACT-CSIC), Avenida de las Palmeras 4, \\ 18100 Armilla, Granada, Spain \\ 7 Instituto Interuniversitario de Investigación del Sistema Tierra en Andalucía (IISTA), Avenida del \\ Mediterráneo s/n, 18006 Granada, Spain; mivalag@ugr.es \\ 8 HEMAV SL, Carrer d'Esteve Terrades 1, 08860 Castelldefels, Spain \\ * Correspondence: cristirecar@gmail.com or cristinarc@ugr.es
}

Received: 17 February 2020; Accepted: 27 February 2020; Published: 3 March 2020 updates

\begin{abstract}
Landslides in reservoir contexts are a well-recognised hazard that may lead to dangerous situations regarding infrastructures and people's safety. Satellite-based radar interferometry is proving to be a reliable method to monitor the activity of landslides in such contexts. Here, we present a DInSAR (Differential Interferometric Synthetic Aperture Radar) analysis of Sentinel-1 images that exemplifies the usefulness of the technique to recognize and monitor landslides in the Rules Reservoir (Southern Spain). The integration of DInSAR results with a comprehensive geomorphological study allowed us to understand the typology, evolution and triggering factors of three active landslides: Lorenzo-1, Rules Viaduct and El Arrecife. We could distinguish between rotational and translational landslides and, thus, we evaluated the potential hazards related to these typologies, i.e., retrogression (Lorenzo-1 and Rules Viaduct landslides) or catastrophic slope failure (El Arrecife Landslide), respectively. We also observed how changes in the water level of the reservoir influence the landslide's behaviour. Additionally, we were able to monitor the stability of the Rules Dam as well as detect the deformation of a highway viaduct that crosses a branch of the reservoir. Overall, we consider that other techniques must be applied to continue monitoring the movements, especially in the El Arrecife Landslide, in order to avoid future structural damages and fatalities.
\end{abstract}

Keywords: DInSAR; Sentinel-1; reservoir safety; landslides; geomorphological mapping

\section{Introduction}

Slope instability is a major problem in the planning, design, construction and maintenance of dams and reservoirs [1]. Until the well-known 1963 Vajont Reservoir slide in Italy, with 2000 fatalities [2], 
experts did not fully realise the potential risk represented by unstable slopes within reservoir basins [3]. After the Vajont case, examples worldwide remind us of this problem: Grand Coulee Reservoir in USA [4], Tabachaca Reservoir in Peru [5], Geheyar Reservoir [6] and Three Gorges Reservoir [7] in China, Nechranice Reservoir in Czech Republic [8], Orava Reservoir in Slovakia [9], Wloclawek Reservoir in Poland [9] and Cortes [10] and Yesa Reservoirs [11] in Spain. These are well-documented cases, worth mentioning, in which ground instabilities within reservoirs produced threatening situations.

There are several phenomena that may produce ground instabilities and dangerous situations in reservoirs. First, the water level changes play a central role in triggering landslides in reservoir slopes [12]. Second, if dam abutments rest on moving slopes, progressive deformation of the dam could lead to its collapse and generate a subsequent catastrophic flood [13]. Rapid large landslides in subaerial or submerged portions of reservoir basin slopes can also generate catastrophic floods due to the creation of impulse waves of great destructive power (see Gutiérrez et al., 2011 [11]). These impulse waves or landslide-related tsunamis can have devastating consequences. As in the Vajont case [2], the wave can overtop or destroy the dam and create a massive flash flood downstream.

Monitoring dams and reservoir unstable slopes is crucial to avoid or minimise the mentioned disasters. In recent years, the use of remote sensing techniques to monitor the activity of slopes that interact with human infrastructures has significantly grown [14]. Some of these techniques are photogrammetry [15], Terrestrial Laser Scanner (TLS) [16], Global Positioning Systems (GPS) [17] and Synthetic Aperture Radar Interferometry (InSAR) satellite-based [18] and ground-based [19]. In particular, the contribution of satellite radar interferometry is becoming one of the most useful tools for ground instability identification and monitoring [20-26]. InSAR monitoring has proven its effectiveness not only in detecting unstable areas on reservoir slopes but also in monitoring the stability of dams. For example, Sousa et al. 2014 [27] discuss the potential of InSAR technology for monitoring deformations in dams and bridges. Milillo et al. 2016 [13], Wang et al. 2011 [28] and Cignetti et al. 2016 [29] also proved InSAR's effectiveness in monitoring the slopes in the Pertusillo (Italy), the Three Gorges (China) and the Beauregard (Italy) dams, respectively. Moreover, Wang et al. 2013 [30] also validated the use of InSAR to locate and monitor landslides in the surrounding areas of the Wudongde Reservoir (China).

The recent increase in the number of satellites with different spatial and temporal resolutions has supposed a step forward in radar techniques [31]. A significant improvement is given by the new C-band sensors on-board the Sentinel-1A and Sentinel-1B satellites, launched on 2014 and 2016, respectively [32]. Sentinel-1 satellites have improved data acquisition and analysis, as its images are free-of-charge and offer wide area coverage, high temporal resolution (sampling of 6 days) and high coherent interferograms [20]. These advantages make possible to monitor surface ground deformation at a high accuracy (up to $1 \mathrm{~mm} /$ year), that, in turn, allows long-term geohazard management over local and regional areas [33].

In this paper, Sentinel-1 data combined with classical geomorphological surveys were evaluated as quick decision-support tools on critical infrastructures. We describe a study in the Rules Reservoir (southern Spain) where unstable slopes represented a particular challenge for its design, construction and management. This study exemplifies how Sentinel-1 based DInSAR (Differential Interferometric Synthetic Aperture Radar) allows the identification of active ground instabilities and provides support on their characterization. Moreover, this study has been developed independently of the authorities responsible for managing the reservoir and the rest of the nearby infrastructures. Thus, the current freely available remote sensing data from European Space Agency (ESA) enabled us to make an independent and continuous assessment of critical infrastructures.

\section{Background}

\subsection{The Rules Reservoir}

The Rules Reservoir is located half-way through the Gualdalfeo River course at its confluence with the Ízbor River, in Granada province (Southern Spain) (Figure 1). The reservoir was initially 
projected to have a maximum water storage of $117 \mathrm{hm}^{3}$ and a flooded area of $3.08 \mathrm{~km}^{2}$ [34]. It collects water from Sierra de Lújar, Sierra de los Guájares and the southern slopes of the western termination of Sierra Nevada (Figure 1). The Rules Dam is a $118 \mathrm{~m}$ high gravity dam that is situated at the southern edge of the reservoir (Figure 1). The structure of the dam is made of vibrated concrete with a $500 \mathrm{~m}$ radius curved plant. The reservoir was initially projected for the following purposes: irrigation (40\%), supply to residential developments on the coast (19\%), energy generation (9\%), flood control (30\%) and environmental flow (2\%) [35]. The inauguration of the reservoir was in 2004, however, neither a water irrigation system nor the hydroelectric power plant have been installed yet.

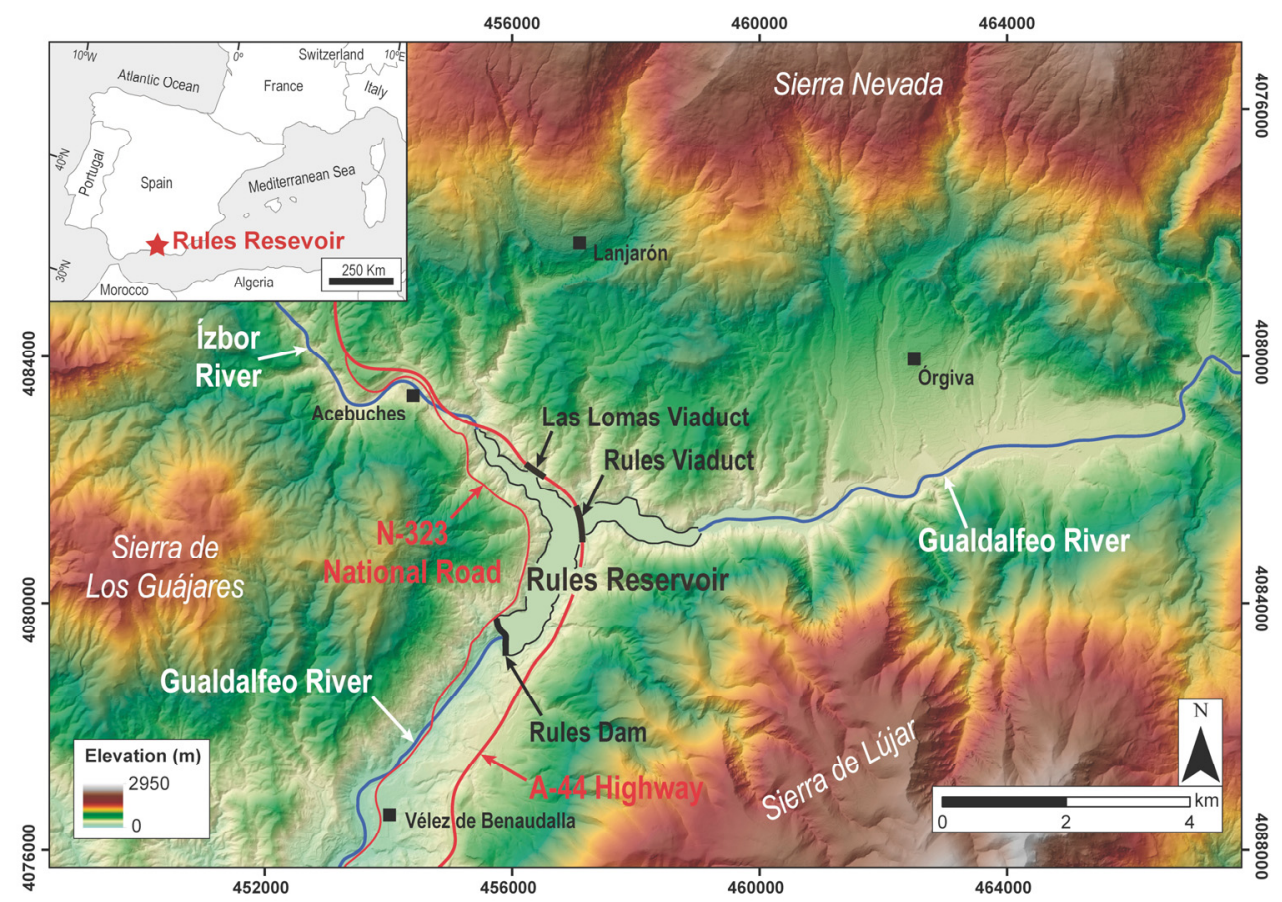

Figure 1. Location of the Rules Reservoir and the main geographical features of the area.

Two important transport infrastructures are spatially associated to the reservoir. Along its eastern bank, the A-44 Highway crosses one of the reservoir branch above a $585 \mathrm{~m}$ length concrete viaduct, called the Rules Viaduct (Figure 1). This highway runs from northern Andalusia, goes through Granada province to the south and ends in the touristic county called 'Costa Tropical' or 'Granada Coast'. Likewise, the N-323 National Road runs through the western bank of the reservoir (Figure 1), having a similar route to the A-44 Highway. The N-323 road was the only connection to the Granada Coast before the A-44 construction in 2009.

\subsection{Geological and Geomorphological Setting of the Rules Reservoir}

The Rules Reservoir is located in the Internal Zones of the central Betic Cordillera, the Iberian part of the Betic-Rif orogen [36]. The Betic Internal Zones are constituted of Mesozoic and Paleozoic rocks, usually metamorphosed and intensely deformed. Our study area is situated over the Alpujárride Complex, one of the three main units of the Internal Zones, and consists of, from bottom to top: i) dark schists ii), quartzschits, iii) phyllites and quartzites and iv) dolomitic marbles [37]. The Rules Reservoir lays within both the Alpujárride phyllites and dolomitic marbles (see geological map of Aldaya et al. 1979 [38]). The deformation history of the Alpujárride Complex was quite complex, resulting in highly folded and fractured rocks (see [37,39-42] for detailed geological research of the area).

From a geomorphological point of view, the Rules Reservoir is situated at $279 \mathrm{~m}$ above sea level in a sediment-filled V-shapped valley excavated by the Gualdalfeo River, mainly in the Alpujárride Complex phyllites. The Sierra de los Guájares and Sierra de Lújar, reaching 1200 and 1800 m, respectively, 
in elevation, constitute the eastern and western limits of the reservoir (Figure 1). Sierra Nevada corresponds to the reservoir northern divide, reaching up to $3400 \mathrm{~m}$ (Figure 1). The elevation of these ranges generates high topographic gradients, as the local relief is $3000 \mathrm{~m}$ maximum at just 35 kilometres from Sierra Nevada to the coastline. Such gradients have led to a deep fluvial incision that triggers abundant slope instability processes in this area [43]. Consequently, several landslide inventories have been produced along the Ízbor and Gualdalfeo River basins [43,44]. Moreover, Irigaray et al. 2000 [45] carried out a landslide susceptibility analysis of the area, associating the highest susceptibility areas to the Alpujárride phyllites.

From the climatic point of view, the Rules Reservoir area has registered a mean annual precipitation of 340-370 $\mathrm{mm}$ and an average annual temperature of $12{ }^{\circ} \mathrm{C}$. A significant part of the precipitation is recorded in winter and spring, while the drier months correspond to summer, typical of the hot-summer Mediterranean climate (Csa), according to the Köppen climate classification. Intense rainfall events and the occurrence of landslides have also been pointed out by Irigaray et al. 2000 [45] in the area, linked to the extraordinarily heavy rains that occurred during the 1996-1997 hydrological cycle.

\subsection{Slope Instabilities Registered in the Rules Reservoir Area}

After the Rules Reservoir inauguration in 2004, the northern edge of the Rules Viaduct was bent during its construction in 2006. Strengthening of the foundations of the damaged viaduct piers was carried out and the infrastructure (and thus, that A-44 Highway section) was inaugurated in 2009 [46]. According to the information provided by the Spanish Ministry of Public Works and Transport, this highway section required an investment of 14 million Euros per kilometre, being the most expensive highway section ever built in Spain [47]. Just 4 years later, in August 2013, the Ministry of Public Works and Transport reported on instability problems in the northern embankment of the viaduct and the required repaired works cost 19 million Euros [48]. The works consisted of the substitution of the embankment with an additional mixed steel and concrete viaduct, the construction of lateral retaining piles and an additional pile closer to the abutment. Road traffic was temporary diverted to the N-323 National Road, which also required major repairs (estimated at 3.8 million Euros) due to its deterioration [49]. Water level fluctuations were pointed out as the main reason for the long-term instability issues in the reservoir [50]. Finally, the viaduct was re-inaugurated in 2015 and no other problem has been reported to date.

Despite of these precedents, no information about the activity of ground instabilities in the Rules area was published until Lackezy et al. 2016 [51]. This research emphasises the potential of InSAR for the detection of moving slopes and compiled several active landslides from different worldwide locations, including a sector of the Rules Reservoir area. The authors processed ENVISAT and Sentinel-1 images, detecting several areas with active movements, but they did not delimit any perimeter of a sliding body nor develop further research on the Rules Reservoir slopes.

\section{Methods}

In order to evaluate the current ground and structure stability in the area of the Rules Reservoir, we firstly applied Differential Synthetic Aperture Radar interferometry (DInSAR) techniques by exploiting Sentinel-1 A and B images. After a comprehensive interpretation of the InSAR results and identification of the main areas showing ground instability, we carried out a thorough compilation of data from these areas and a detailed geomorphological field survey. We inventoried field evidences of the detected movements and produced several geomorphological maps at site scale of the unstable areas (i.e., active landslides). In parallel, we analysed the time series of displacement in the unstable measured points. We were interested in checking the evolution of the displacements and their link to possible triggering factors such as rainfall and water level variations in the reservoir. 


\subsection{SAR Interferometry}

In order to derive the velocity map and the time series of displacements (TS), we applied the Persistent Scatterer Interferometry chain of the Geomatics Division (PSIG) of the Centre Tecnològic de Telecomunicacions de Catalunya (CTTC), described by Devanthéry et al. 2014 [52]. The procedure and the main parameters are resumed in the flowchart of Figure 2. After the generation of the interferograms, the first step was the estimation of the annual linear velocities over a selection of points (see $[53,54]$ for more details). Then, over the same selected points, the accumulated displacement at each image date was calculated based on a two-steps phase unwrapping (see [31], [52] and [55] for more details). The estimation of the annual linear velocity and the time series were both estimated along the satellite Line of Sight (LoS) direction. Therefore, the final output of the processing procedure was a surface displacement map that consists of a set of selected points with both the information of the estimated LoS velocity (i.e., velocity maps) and the accumulated displacement at every satellite acquisition (i.e., time series). We processed one burst of 139 Sentinel-1A and Sentinel-1B images, acquired on ascending orbits with a temporal sampling up to 6 days and covering a period from 10 March 2015 to 20 September 2018. Table 1 shows the further characteristics of the used images dataset and other processing parameters. To derive the velocity maps and the time series, we generated 6664 interferograms. In order to optimize the two processing approaches, we used long a temporal baseline observation (i.e., interferograms with a minimum temporal baseline of 150 days) to derive the annual linear velocities and a short temporal baseline observation (i.e., interferograms with a maximum temporal baseline of 60 days) to derive the displacement. This selection of the interferograms network improves the results in terms of noise and spatial coverage. The reference point to calculate the velocities was located in a small urbanised area to the south of the reservoir (N36 $51^{\prime} 18.678^{\prime \prime}$; W $\left.3^{\circ} 29^{\prime} 43.983^{\prime \prime}\right)$. According to the Barra et al. 2017 [31] criterion, we estimated the stability range of the velocity map, and, therefore, the threshold for discriminating stable and unstable targets, as two times the standard deviation of the velocity of all the measured points. This stability range also represents the general noise of the results, i.e., the sensitivity of the velocity map. Hence, points classified as 'stable' can be truly stable as well as unstable points, with an undetectable displacement [31].

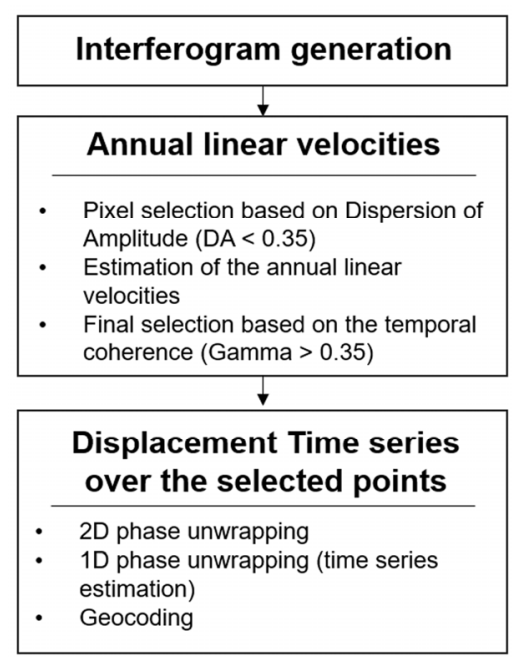

Figure 2. Flowchart resuming the main steps of the DInSAR processing. Refer to [53-55] for further details. 
Table 1. Main characteristic of the processed SAR data.

\begin{tabular}{cc}
\hline Satellite & Sentinel-1A and B \\
\hline Acquisition mode & Product type \\
Orbit & Interferometric Wide (IW) Swath \\
Incidence angle & Ascending \\
Track or relative orbit number & $39^{\circ}$ \\
Minimum revisit period (days) & 1 \\
Temporal span & 6 \\
Number of images & March 2015-September 2018 (3.5 years) \\
Wavelength (cm) & 139 \\
Polarization & 5.5 \\
Full resolution (azimuth/range) $(\mathrm{m})$ & VV \\
Number of processed swaths & $14 / 4$ \\
Number of processed bursts & 1 \\
\hline
\end{tabular}

\subsection{Geomorphological Investigation}

After obtaining the InSAR results, we performed a general overview of the velocity map to define unstable areas. We compiled the published scientific literature of the area as well as historical documents, aerial photographs (1956-1957 American Flight and 2004 to 2017 from the PNOA project) and press reports until the present. Once we gathered such information, we carried out a comprehensive geomorphological survey at site scale of the areas of interest. We performed a detailed photointerpretation and field survey combined with the exploitation of the available digital data in a GIS environment: Digital Elevation Models and derived information (e.g., hillshade and slope maps) as well as 2014 LiDAR data. All the digital data was freely obtained at the IGN web page (www.ign.es), the Spanish National Geographic Institute. Thus, we produced a landslide inventory map of the reservoir and three geomorphological maps for each studied unstable area, after and before the construction of the reservoir, to illustrate the landscape evolution.

\subsection{Analysis of InSAR Times Series}

We analysed the Time Series of displacement (TS) of the unstable points within the three areas of study. Prior to this analysis, the TS of each unstable area have been referenced to a stable neigbour point. This significantly reduced the effects of residual atmospheric artefacts. The goal of the analysis was to assess the temporal behaviour of each slope and its relation to possible triggering factors. To this end, we compared the displacement time series with rainfall and reservoir water level variations. Rainfall and reservoir water level measurements were freely obtained from the public Andalusian Automatic System of Hydrologic Information (S.A.I.H. HIDROSUR, www.redhidrosurmedioambiente.es). Rainfall data correspond to the pluviometric station number 50, located within the village of Vélez de Benaudalla (Figure 1).

\section{Results}

\subsection{InSAR Velocity Map of the Rules Reservoir}

We measured the velocity of 28,137 points within the Rules Reservoir area (Figure 3). The obtained data allowed us to settle the stability range between 5 to $-5 \mathrm{~mm} /$ year. According to these criteria, we identified 406 non-stable points, which represent $1.4 \%$ of the total points. As velocity is estimated along the satellite Line of Sight (LoS) direction, the points of negative values evidence points move away from the satellite, while positive values evidence points move towards the satellite. Taking into consideration that the SAR images were acquired in ascending orbit, positive and negative values may indicate, in addition to uplift and subsidence displacements in flat areas, westward and eastward movements in the slopes of the reservoir, respectively. 


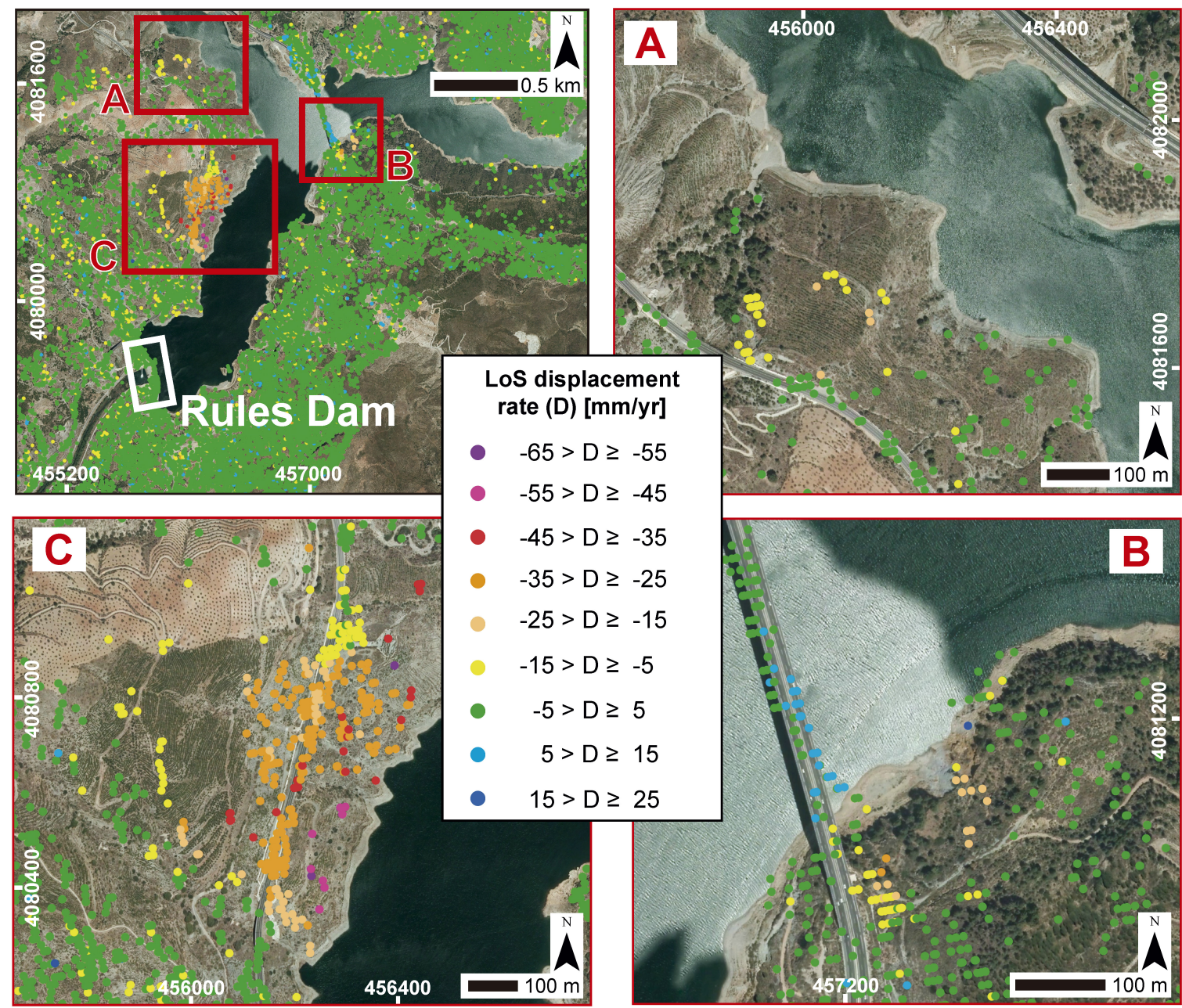

Figure 3. Surface velocity map of the Rules Reservoir area. The Cortijo de Lorenzo area (A), the Rules Viaduct Landslide (B) and the El Arrecife Landslide (C) are shown in greater detail.

The non-stable points are concentrated mainly in three areas (Figure 3): (A) the Cortijo de Lorenzo area, along the Ízbor River branch of the reservoir, (B) the southern edge of the Rules Viaduct and (C) the El Arrecife area, along the western slope of the Rules Reservoir. The Cortijo de Lorenzo area generally presents evidence of slope instability, mainly linked to a landslide that we named as Lorenzo-1 Landslide. Velocity rates reach $20 \mathrm{~mm} /$ year as maximum (Figure 3A). In the southern slope of the Rules Viaduct, we detected velocities in the range of -5.5 to $-24 \mathrm{~mm} /$ year (Figure 3B), with $-15 \mathrm{~mm} /$ year as the mean velocity. Most of the points are settled close to the viaduct itself, while another set of points are settled $150 \mathrm{~m}$ away to the northeast of the viaduct (Figure 2B), located within a landslide that was inventoried by Fernández et al. 1997 [43] and Chacón et al. 2007 [44]. We named this landslide as 'Rules Viaduct Landslide'. Lastly, in the El Arrecife area, we obtained velocities ranging from -10 to $-60 \mathrm{~mm} /$ year and the mean velocity was $-25 \mathrm{~mm} /$ year. Most of the points are distributed along the N-323 National Road and the lowest part of the same slope (Figure 3C). The set of points with the highest velocities (around -50 and $-55 \mathrm{~mm} /$ year) corresponded to a small-sized landslide also inventoried by Fernández et al. 1997 [43] and Chacón et al. 2007 [44]. The instability of this area was also pointed out by Lackezy et al. 2016 [51], but the spatial pattern of the velocities obtained by these authors prevents a detailed delimitation of the sliding mass. Our surface velocity map gave us a better insight into the landslide boundaries that we named as 'El Arrecife Landslide'. Additionally, we could observe that the southern lateral limit of this landslide shows an abrupt change in terms of velocity values, while the northern limit shows a gradual velocity evolution (Figure 3C). 
From our InSAR data, we also found out that the Rules Dam and the slopes on which the structure rests show no displacement (Figure 3). Within both slopes, Fernández et al. 1997 [43] firstly mapped two large landslides that we named as 'Ventura Landslide', a Deep-Seated Gravitational Slope Deformation (DSGSD), and 'Los Hoyos Landslide', a rock slope failure (RSF) of the lateral spread type (Figure 4). Moreover, other critical structure in the study area seems to be affected by a slight deformation also detected through our DInSAR analysis. Along the southern edge of the Rules Viaduct, we obtained a set of points showing positive values of displacement rates between 7 and $10 \mathrm{~mm} /$ year (Figure 3B), which indicates a slight displacement of this viaduct segment.

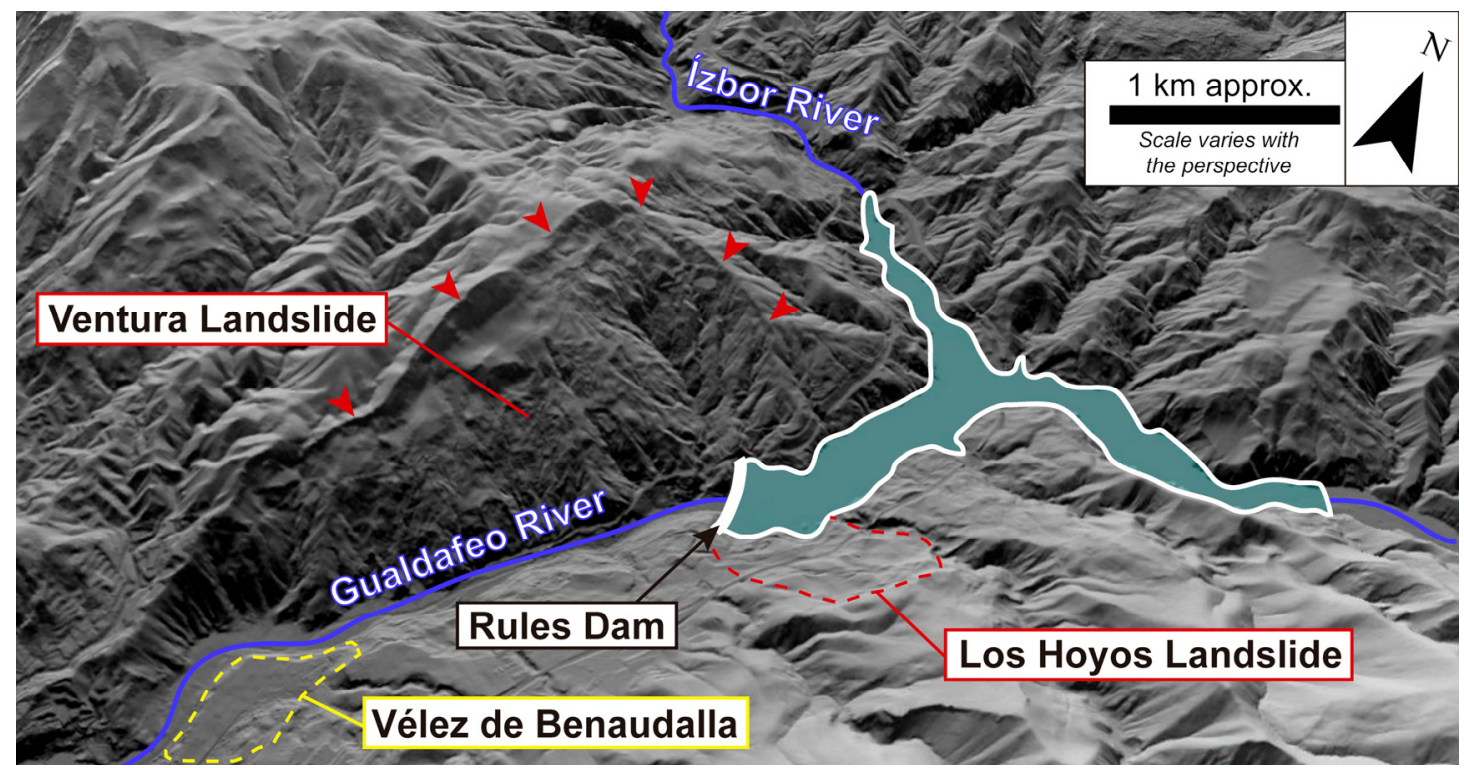

Figure 4. Oblique northwestward view of a hillshade model of the Rules Resevoir area. Red triangles point out to the main scarp (i.e., crown) of the Ventura landslide, its most clear geomorphic feature. Note the dimensions of the Los Hoyos Landslide and Ventura Landslide at both sides of the Rules Dam.

\subsection{Geomorphological Study}

We present an inventory of the main landslides in the Rules Reservoir area by classifying the mapped landslides into three categories (Figure 5): (1) landslides already inventoried by Fernández et al. 1997 [43] and Chacón et al. 2007 [44], (2) new landslides detected and delimited by using InSAR velocity maps, and (3) landslides that were inventoried by Fernández et al. 1997 [43] and Chacón et al. 2007 [44], and also evidenced by our InSAR results.

According to the first category, we included those landslides that were considered in the Fernández et al. 1997 [43] landslide inventory and are clearly recognisable in the landscape at the present time. We inventoried twelve landslides of different dimensions, two of which we consider to be of particular relevance: 'Ventura Landslide' and 'Los Hoyos Landslide', due to its direct relationship to the Rules Dam (Figures 4 and 5). As mentioned above, we did not detected displacement within both landslides. The second category includes the 'El Arrecife Landslide' (Figure 5) that we delimited in terms of the non-stable InSAR points distribution. This landslide is not easily identifiable in the landscape as it does not show a prominent head scarp or any other landslide-related morphology within the slope. The last category includes two landslides that were inventoried by Fernández et al. 1997 [43] and Chacón et al. 2007 [44] and also present evidences of activity by our InSAR results. These landslides are the 'Rules Viaduct Landslide', located next to the southern edge of the Rules Viaduct, and the 'Lorenzo-1 Landslide', located in the Cortijo de Lorenzo area, along the Ízbor River branch of the Rules Reservoir (Figure 5). Further geomorphological characteristics of each area of study are described below. 


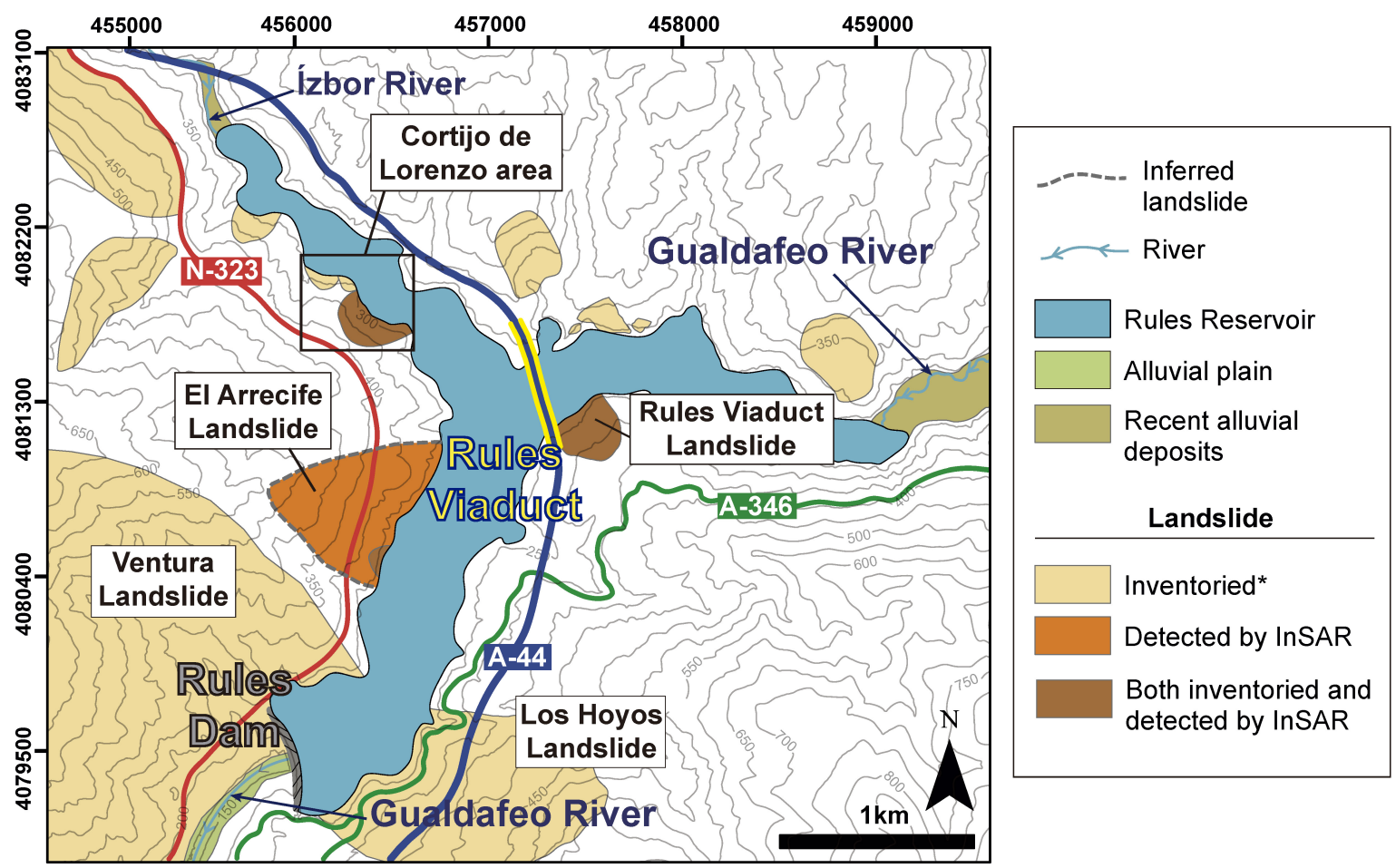

Figure 5. Landslide inventory of the most representative landslides of the Rules Reservoir area.

* Landslides inventoried by Fernández et al. 1997 [43] and Chacón et al. 2007 [44].

\subsubsection{Cortijo de Lorenzo area}

The Cortijo de Lorenzo consists of an area of $0.6 \mathrm{~km}^{2}$, located in the northwestern part of the Rules Reservoir (Figure 5) and corresponding to the Ízbor River branch of the reservoir. We mapped three landslides in this area (Figure 6): (1) Lorenzo-1 Landslide, which is the biggest one and clearly shows morphological features of a rotational landslide. It was already inventoried by Fernández et al. 1997 [43] and Chacón et al. 2007 [44] (Figure 5); (2) Lorenzo-2 Landslide, the smallest landslide; and (3) Lorenzo-3 Landslide, that is considerably older than the others (grey-coloured in Figure 6) as it is almost covered by vegetation and presents alluvial erosion features (Figure 7A). All of these landslides involve Alpujárride phyllites. At the present time, the reservoir water has covered a considerable part of these landslides, which is especially noticeable within Lorenzo-3 Landslide (Figure 6B). In the field, we observed several opened and fresh cracks within the landslide, what indicates its activity. We also found opened cracks and active piping away from the landslide perimeter (Figure 7B), that evidences a landslide retrogression towards the west of the slope. These field observations are corroborated by the moving points of our InSAR velocity map (Figure 3A). The reconstruction and resettlement of the N-323 National Road has slightly modified the surface runoff dynamics along a well-incised creek (Figure 6). Part of this new trace has been recently resurfaced and it presents a large bump that crosses the road (Figure 7C), probably due to slope instability processes along the creek that have also been evidenced by our InSAR results (Figure 3A). 


\section{CORTIJO DE LORENZO AREA IN 1956}

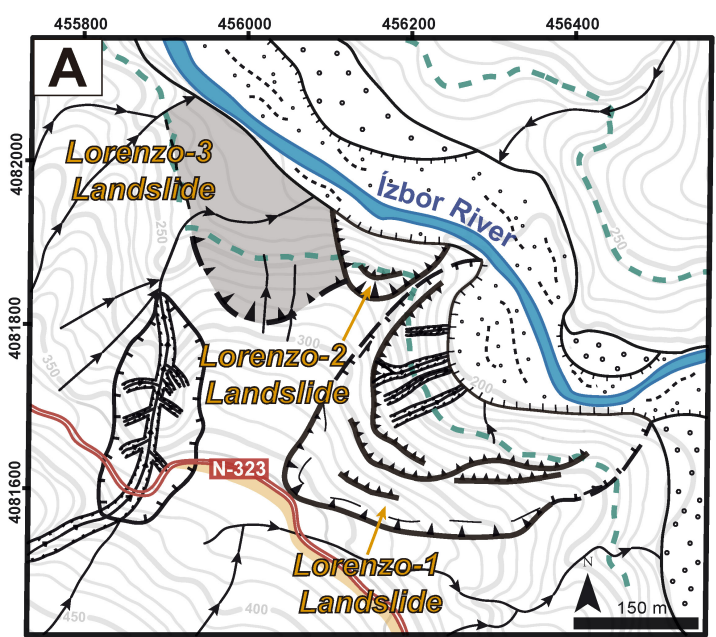

\section{CORTIJO DE LORENZO AREA AT PRESENT}

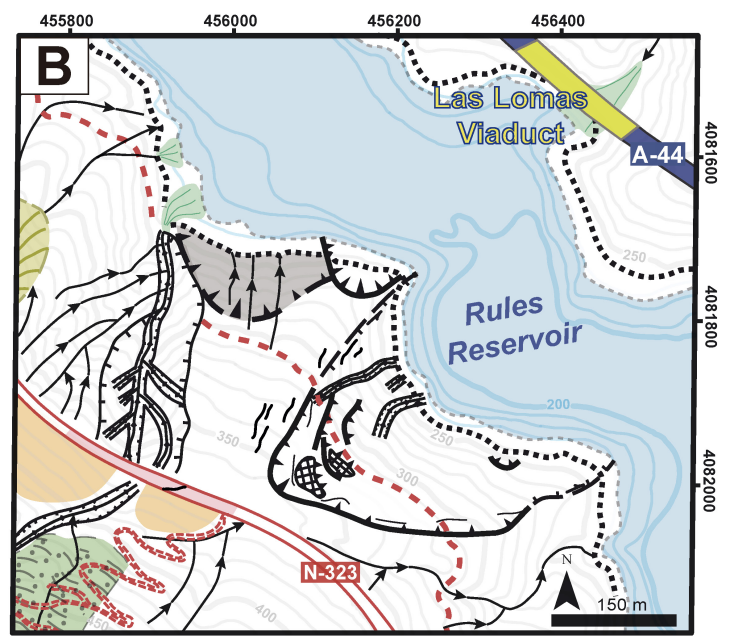

Slope movements

エ工. Main scarp $ح$ Cracks

$\boldsymbol{\nabla} \boldsymbol{\nabla}$ Degraded main scarp

$\boldsymbol{T}$ Secondary scarp

$\Gamma \Gamma,-$ Lateral break of slope

$\Longrightarrow$ Shear direction of movement

- . - . Inferred landslide boundary

Bench [-... Old landslide scar
Man-made features

....... Maximum reservoir capacity

- - - Current maximum level of the reservoir

z:=-z=-z Dirt road $=$ Road

Reservoir $\square$ viaduct $\square$ Highway

Resurfaced road $\approx$ Slagheap

[.-.] Terrace cultivation Road-cut slope
Fluvial and surface runoff features

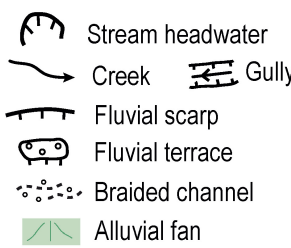

Figure 6. Geomorphological maps of the Cortijo de Lorenzo area in 1956-1957 (A) and at present (B).

\subsubsection{Rules Viaduct Landslide}

Through the aerial photographs taken by the 1956-1957 American Flight, we were able to map several geomorphological features that had been highly modified or disappeared since the construction of the reservoir (Figure 8). The landslide had an area of $0.1 \mathrm{~km}^{2}$ (345 m length and $330 \mathrm{~m}$ width) and a clear head scarp with an amphitheatre shape (Figures 8 and 9A). The slope morphology and the involved geomorphological features have led us to define this landslide as a retrogressive rotational type. This is evidenced by a system of secondary scarps and related benches, as well as by a big tilted block of marbles (Figure 8A). In such cases, the overlying Alpujárride marbles slide over the phyllites, as we could observe in the main head scarp and also in some secondary scarps We classified the western part of the landslide as a differentiated and active landslide, whose morphology is evidenced by separated head scarps, secondary scarps, benches and a well-defined lateral break in slope (Figure 8A). We induced its activity as we could observe a clear toe advance of this landslide, not observed within the presumed non-active sector (Figure 8A). Alluvial erosion and the formation of gullies also evidence no movement and stability in this part of the landslide. As previously mentioned, most of the original geomorphological features have been removed, modified or covered by man-made filling (Figure 8B). In this way, the landslide toe has been removed and covered by the reservoir water, while the western sector (i.e., active landslide) has been replaced by an embankment for the Rules Viaduct, where one of the viaduct piers is located (Figure 8B). Almost the entire remaining landslide has been infilled with materials coming from the construction works. As a consequence, most of the secondary scarps and benches have disappeared. Part of the active landslide and the main scarps are still visible, but secondary scarps and benches have been removed or covered. We found active piping and opened, fresh cracks within the infilling material (Figure 9B,C), especially near the head scarp of the active landslide, which evidences its activity. Cracks are also found away from the landslide perimeter, also covered by infilling materials, and next to the A-44 Highway southern abutment (Figure 9B). 
This field evidence and the displacements shown in the InSAR velocity maps (Figure 3B) indicate a hazardous landslide, with retrogressive evolution towards the west-southwest, i.e., towards the southern abutment of the viaduct.

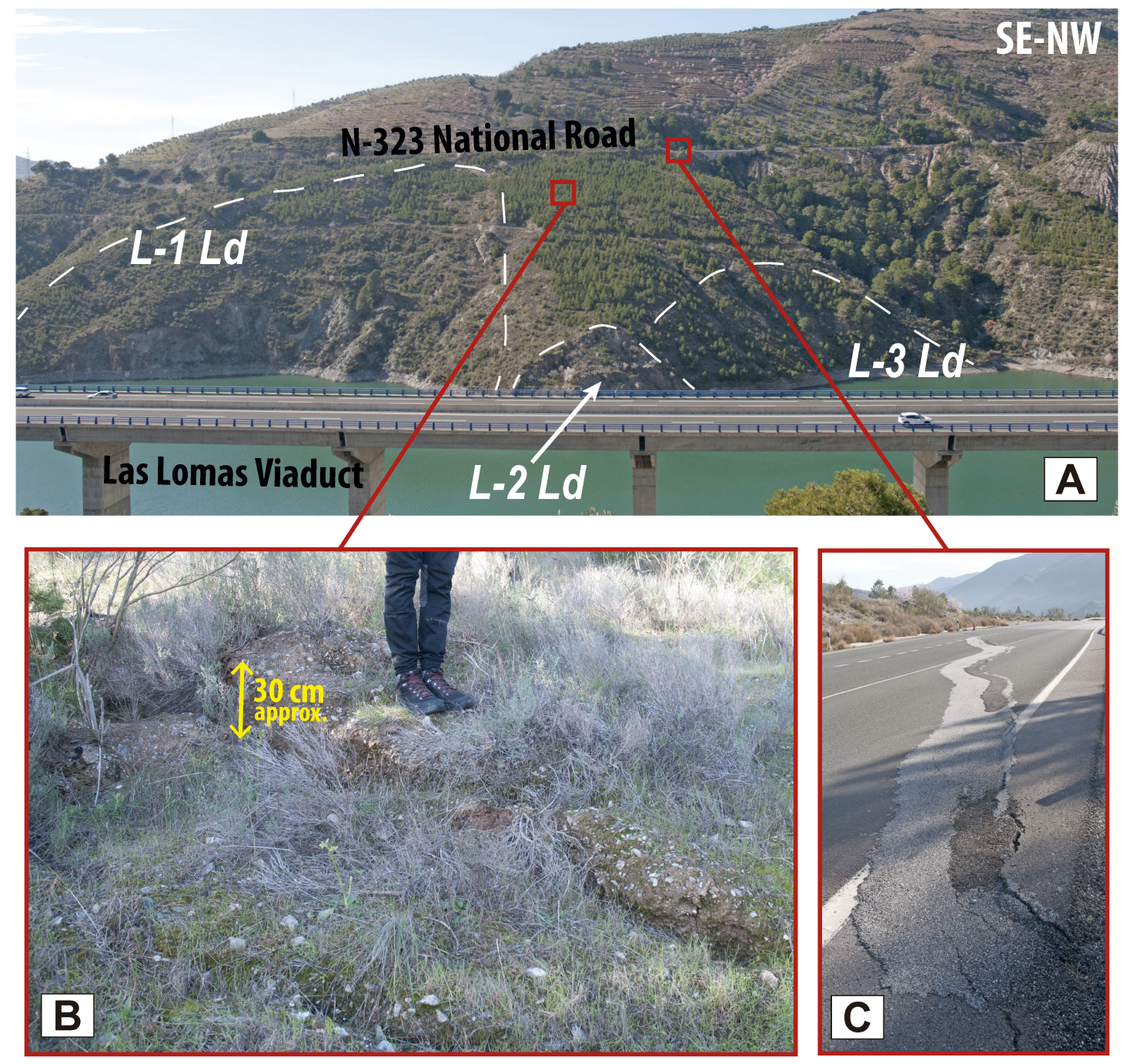

Figure 7. (A) Photograph of the Cortijo de Lorenzo area. The Lorenzo-1 Landslide, Lorenzo-2 Landslide and Lorenzo-3 Landslide are abbreviated as L-1 Ld, L-2 Ld and L-3 Ld, respectively. (B) Opened cracks next to the head scarp of the Lorenzo-1 Landslide. Notice the vertical slip of $30 \mathrm{~cm}$, as maximum. (C) Bump across the N-323 National Road. 
RULES VIADUCT LANDSLIDE IN 1956

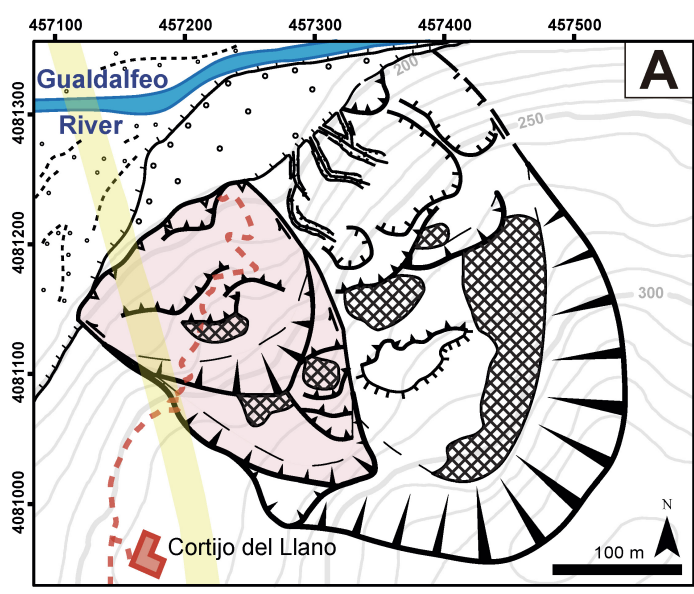

Slope movement features

f Main scarp $\longdiv { \sim }$ Secondary scarp $\Gamma \Gamma$ Lateral break of slope Bench $\nabla \nabla$ Toe advance Displaced block $\leadsto$ Shear direction of movement $\sim$ Cracks - - - Landslide boundary of Rockfall

Active landslide main scarp Active Active landslide boundary landslide
RULES VIADUCT LANDSLIDE AT PRESENT

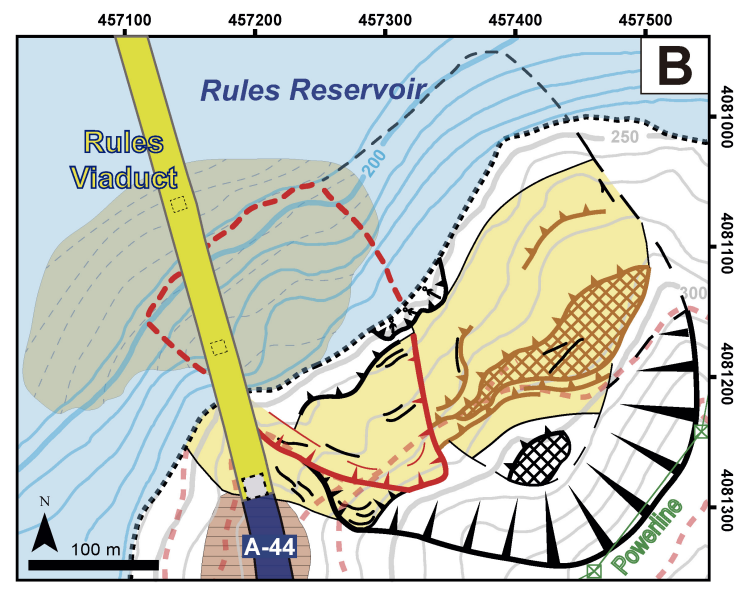

\section{Man-made features}

$\longrightarrow$ Secondary scarp Bench

........ Maximum reservoir capacity

- = - Dirt road - - - Powerline

E-1 Viaduct embankment Reservoir

$\square$ Embankment $\square$ Highway $\square$ Viaduct

: Abutment $:$ Pier Man-made fill
Fluvial and surface runoff features

(n) Stream headwater

?ृ Fluvial terrace

$\because \%::$. Braided channel

Gully
Fluvial scarp

Figure 8. Geomorphological maps of the Rules Viaduct Landslide in 1956-1957 (A) and at present (B).
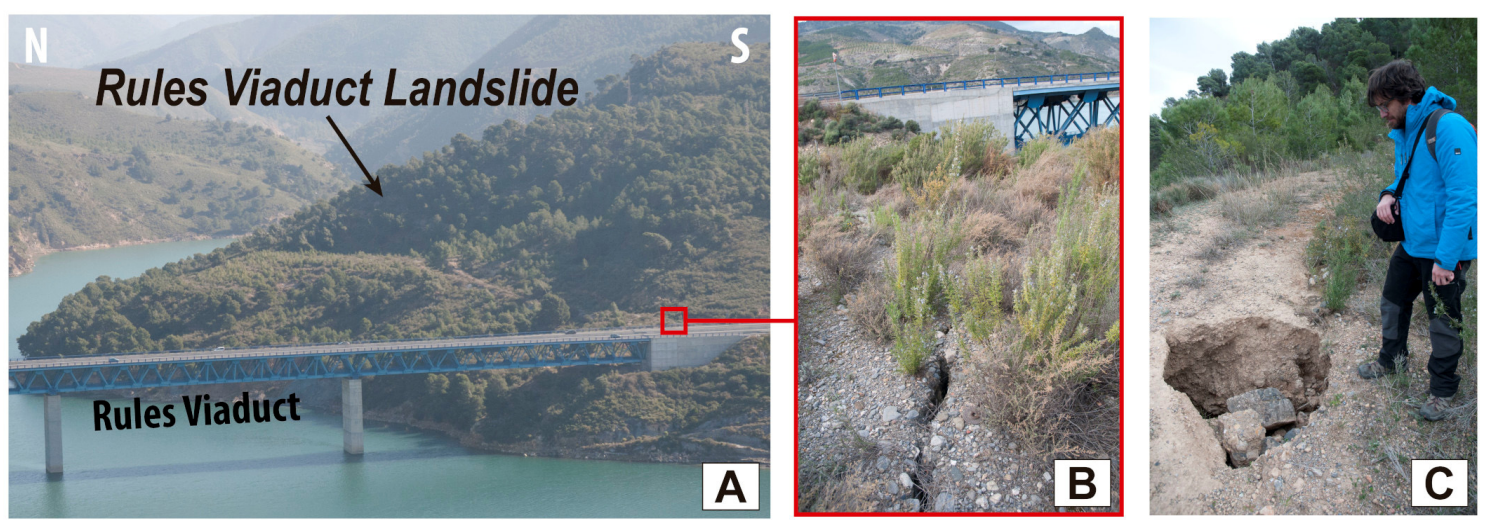

Figure 9. (A) Photograph of the Rules Viaduct Landslide. (B) Opened cracks near the southern abutment of the Rules Viaduct. (C) Sinkhole within the anthropic filling. 


\subsubsection{El Arrecife Landslide}

The El Arrecife Landslide (Figures 10 and 11A) had an area of $0.7 \mathrm{~km}^{2}, 880 \mathrm{~m}$ length and $750 \mathrm{~m}$ width. This landslide involves Alpujárride phyllites and it looks like a translational landslide due to its roughly planar slope and the absence of a well-marked head scarp (Figure 11A). In the 1956-1957 aerial photographs, the landslide shows a non-prominent head scarp and almost no secondary scarp or lateral break of slope (Figure 10A). At the landslide foot, we could recognise a small landslide, inventoried by Fernández et al. 1997 [43] and Chacón et al. 2007 [44]. The slope, crossed by the N-323 National Road, was characterised by several incised gullies (Figure 10A) that indicate an a priori inactivity regarding gravitational processes. At present, the most remarkable features in the slope are the human modifications (Figure 10B). The main one is the road-cut slope built for a new trace of the N-323 road that was reconstructed $80 \mathrm{~m}$ downslope (Figure 10B). Part of the old N-323 is still visible in ruins, where we found numerous large opened cracks and pieces of pavement that have been sliced downhill (Figure 11B). The current road has been restored and resurfaced several times, probably due to the slope instability processes, which are also evidenced by recent oblique cracks, bumps (Figure 11C) and the ondulating surface of the road (Figure 11D). The surface of a slagheap that was built to accumulate some of the residual material coming from the reservoir construction works was also paved to create a viewpoint (Figure 10B), but it has been quickly cracked due to the material compaction and progressive sliding. Other man-made features of the area at present are the construction of several field tracks and a powerline network.

EL ARRECIFE LANDSLIDE IN 1956
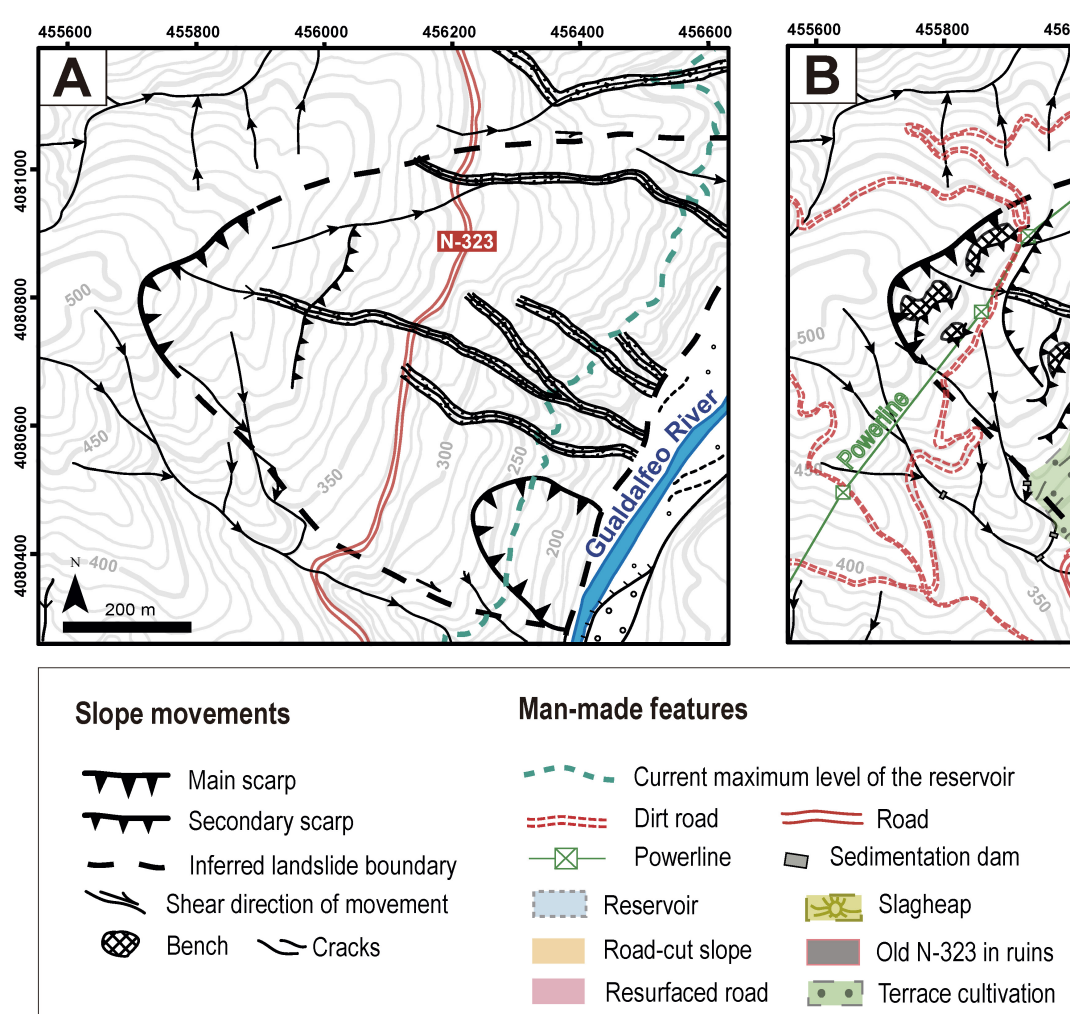

\section{EL ARRECIFE LANDSLIDE AT PRESENT}

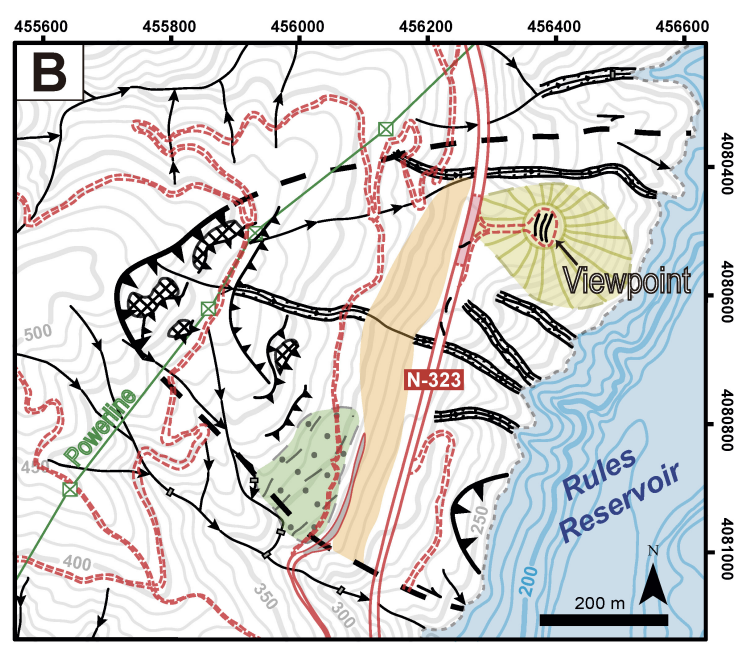

Fluvial and surface runoff features

(7) Stream headwater

$\longrightarrow$ Creek Gully

$\because$ Fluvial terrace

$\because \because \frac{0}{0}$ B Braided channel

Figure 10. Geomorphological maps of the El Arrecife Landslide area in 1956-1957 (A) and at present time (B). 

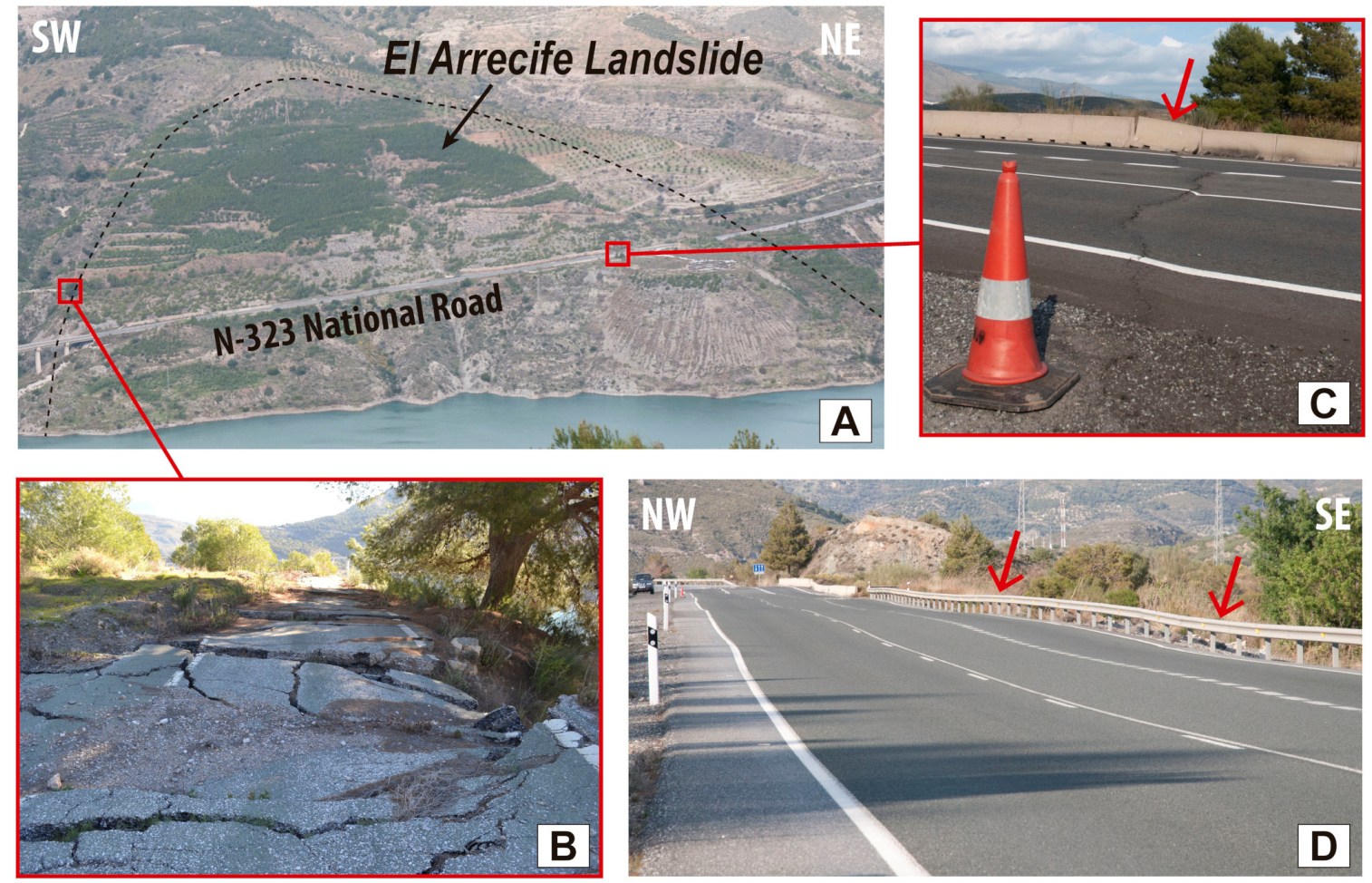

Figure 11. (A) Photograph of the El Arrecife Landslide. (B) Old N-323 National Road in ruins showing opened cracks and partial collapse of the pavement. (C) Bump of the N-323 National Road.

(D) Photograph of the N-323 National Road. Notice the 'waving' of the crash barrier and the road itself.

\subsection{Displacement-Time Series of the Unstable Areas in the Rules Reservoir}

The analysed time series of displacement (TS) are represented by the average accumulated displacement of unstable points within our areas of interest, described in Section 4.1. The El Arrecife Landslide time series shows a general linear trend (Figure 12A), while both the Rules Viaduct Landslide and Lorenzo-1 Landslide average displacement show a well-marked 'steeped' trend (Figure 12B).

The most remarkable fact that we observed was the correlation between the Rules Viaduct and the Lorenzo-1 landslides' TS, with variations in the water level of the reservoir. We identified three considerable drops of the water level that coincide with three periods of acceleration of the movement, that are evidenced by a change in the slope of the average accumulated displacement rate (Figure 12B). The first and the second periods of acceleration corresponds to autumn 2015 and summer-autumn 2016, respectively, while the third and the longest period of acceleration occurs from summer 2017 to winter 2018 (Figure 12B). On the contrary, displacement is not accelerated when water level increases, which depends directly on the amount of rainfall. The El Arrecife Landslide TS shows a slight acceleration period during autumn 2015, also correlated with a decrease in the water level reservoir (Figure 12A). 

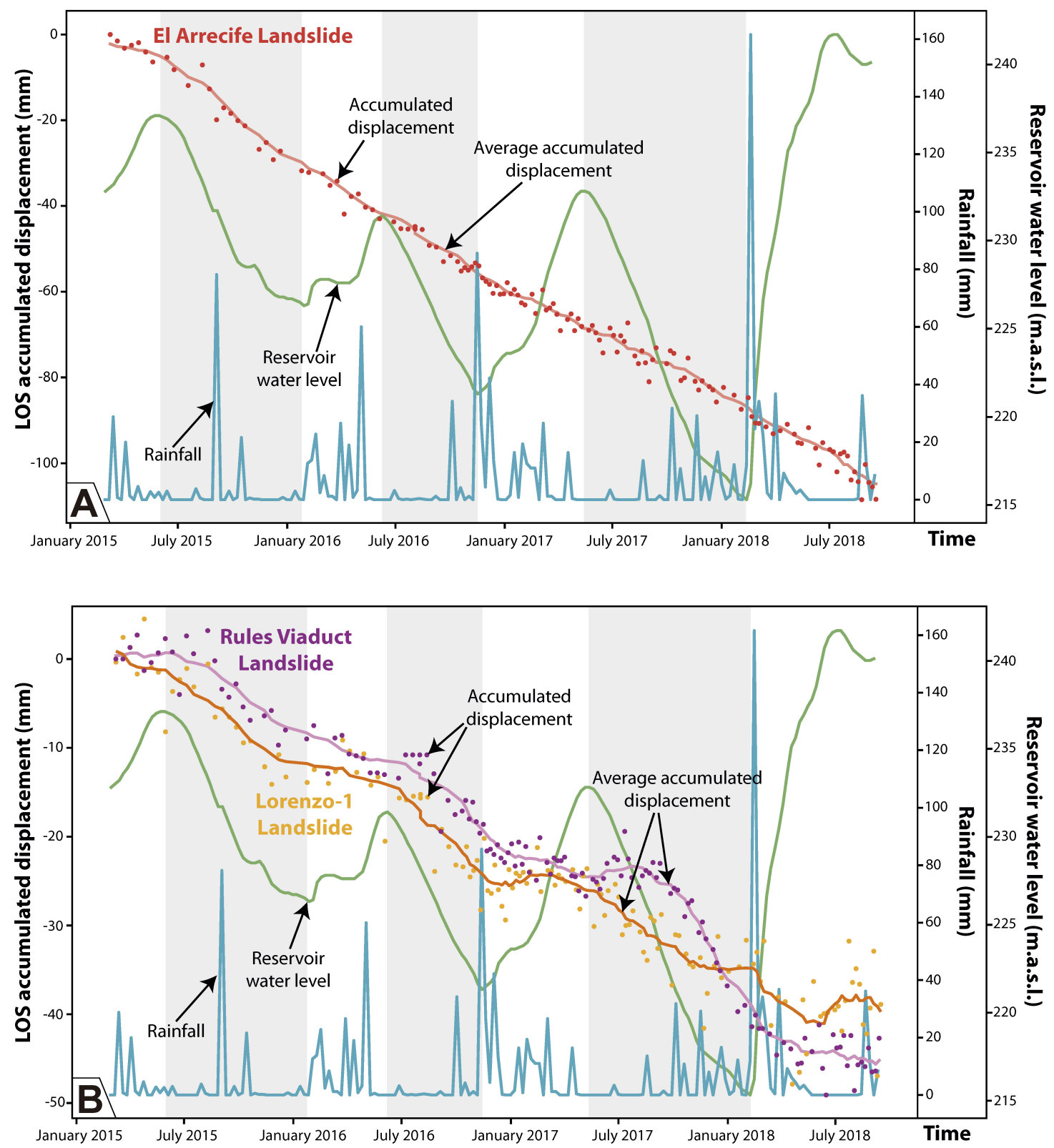

Figure 12. Time series in the line of sight of accumulated displacement of the El Arrecife Landslide (A) and both the Rules Viaduct Landslide and Lorenzo-1 Landslide (B). 7 days cumulative rainfall and water level of the Rules Reservoir are also represented. Grey columns indicate periods of reservoir drawdown.

Regarding the unstable points along the Rules Viaduct, the time series shows periods of displacement coinciding with drawdowns in the water level reservoir (Figure 13). Thus, we identified three acceleration pulses during the springs of 2015, 2016 and 2017 (Figure 13). 


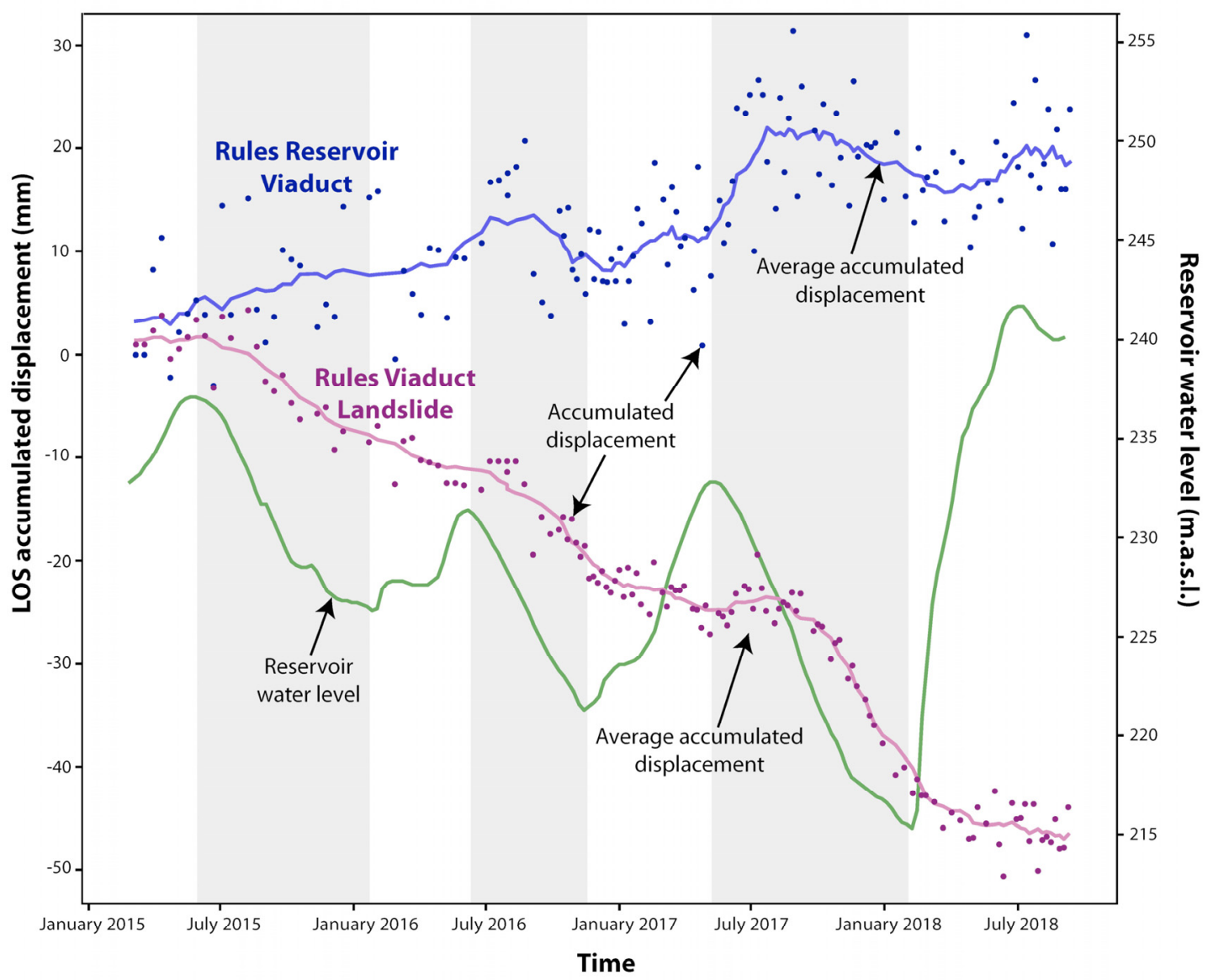

Figure 13. Time series in line of sight of accumulated displacement of the Rules Viaduct Landslide and the Rules Viaduct. Water level of the Rules Reservoir is also represented. Grey columns indicate periods of reservoir drawdown. Note the noise of the Rules Viaduct TS in comparison with the Rules Viaduct Landslide TS.

\section{Discussion}

\subsection{DInSAR as a Monitoring System for the Rules Dam}

Interferometry techniques have a huge potential to monitor and analyse the health of dams, as demonstrated by worldwide examples: $[13,28,56,57]$. For the case study of the Rules Reservoir, we did not register any displacement along the Rules Dam (Figure 3). Likewise, no points of movement have been obtained within the Ventura Landslide and the Los Hoyos Landslides, where the dam abutments are located (Figures 3 and 4). Due to the magnitude of these landslides, we consider that other monitoring techniques should be applied to check the existence of ground displacement, and thus the activity of these landslides. This is necessary as the progressive movement of a sliding mass could generate a lateral pressure to the dam and cause structural damage. Therefore, detecting any slight displacement would be crucial to (1) guarantee the security and stability of the dam, (2) reduce maintenance costs by optimizing control strategies [27] and (3) prevent failure or collapse of the dam, which would cause significant human, material and economic losses (e.g., a downstream flood would affect the village of Vélez de Benaudalla).

\subsection{Triggering Factors of the Slope Instabilities in the Rules Reservoir}

In the case of both the Lorenzo-1 and Rules Viaduct landslides, there is a clear anthropic influence favouring the acceleration of the movements (i.e., anthropic triggering factor): the changes in the water level of the reservoir. As shown in Figure 12B, the three periods of acceleration in both landslides are 
related to periods of drawdown of the water level, while periods of no variation or increase in the water level result in stabilization. Such a correlation has also been documented in multiple reservoirs slides as a result of either filling or drawdown of the reservoir (e.g., [4-11]). In contrast, the sudden drawdown of a reservoir can threaten stability as a result of removing the lateral confining pressure (water) of the reservoir slopes, and the mass of soil still has a reduced shear strength [3]. In the case of the Grand Coulee Reservoir in the USA [4], at least 150 landslides were documented, due to periods of water level drawdown. As another example, in the Three Georges Reservoir area, Liao et al. 2005 [58] concluded that reservoir drawdowns and the descending velocity of the drawdown become major factors that affect the stability of landslides. We also regard the detected inverse relationship between rainfall and acceleration of movement within the above-mentioned landslides as interesting. Rainfall usually reduces the effective shear strength of failure surfaces [59], and thus increases the potential of sliding. This fact has been evidenced by several authors [60-63] that link the reactivation, acceleration or higher occurrence of landslide activity to heavy rainy periods. Contrary to this literature, both the Rules Viaduct Landslide and Lorenzo-1 Landslide show a deacceleration in movement related to rainfall peaks (Figure 12B). As rainfall conducts the reservoir filling, lateral confining pressure increases (as a result of a water level increase) and, thus, landslide displacement decreases, leading to a relative stabilization of the slopes. These examples show how water level variation has a stronger influence on landslide displacement patterns than rainfall. Moreover, this paper represents the first clear detection of this behaviour using DInSAR techniques. The high temporal resolution of the Sentinel- 1 images has made this possible.

\subsection{Characterization of Slope Stabilities and Potential Hazards in the Rules Reservoir}

The abundance of landslides in the Rules Reservoir area was the object of detailed landslide inventories in recent years $[43,44]$. In this regard, slope instability has become an important problem to deal with during the reservoir planning, design, construction, maintenance and management phases. DInSAR allowed us to determine the activity of some well-known landslides, as well as to identify, delimit and map new landslides that are not easy recognisable in the landscape. The three areas of interest of our research are affected by different kind of landslides with respect to their kinematic or size, which also lead to different problems in relation to the reservoir. In this way, DInSAR analysis together with a detailed geomorphological investigation allowed us to characterise and understand the evolution of the landslides, and thus to assess their potential hazard to the Rules Reservoir.

The observed patters in the TS of the three areas of interest, together with our morphological observations, suggest that there are two different typologies of landslides. The Rules Viaduct and Lorenzo-1 landslides show movements correlated to the variation in the reservoir water level that stops and begins again with episodes of progressive acceleration and abrupt decceleration (Figure 12B). This pattern is related to a rotational typology as, according to [64], movement in rotational slides may stop in part after a substantial displacement. On the contrary, the El Arrecife Landslide shows an almost continuous movement with little fluctuation (Figure 12A). Whereas a rotational landslide tends to restore the displaced mass to equilibrium, a translational slide may continue unchecked if the surface of separation is sufficiently inclined [64]. Such a continuous pattern is well-illustrated in the El Arrecife Landslide time series (Figure 12A), and thus we could confirm that it is a translational landslide.

According to the above arguments, the Lorenzo- 1 and the Rules Viaduct landslides, due to their dimensions and rotational character, do not represent a significant hazard for the reservoir shorelines or the dam. An extremely rapid acceleration in these landslides and their sudden collapse into the reservoir may be possible, but is unlikely, due to their characteristics and observed behavior, if reservoir water level management is done properly. However, the main risk associated to these landslides is their retrogressive evolution, that may affect the southern abutment and pillars of the Rules Viaduct (in the case of the Rules Viaduct Landslide) or the N-323 National Road (in the case of the Lorenzo-1 Landslide) in future. Therefore, it must be a priority to keep monitoring the evolution of these landslides as well as to analyse the deformation detected along the southern segment of the Rules Viaduct (Figure 13). If 
the displacements are validated using other geodetic techniques, any required reinforcement works should be carried out far enough in advance to avoid severe damage to the viaduct (as happened in the last decade) in order to reduce repair costs. The origin of this deformation is still unknown, but we have hypothesised different scenarios to explain it: (1) horizontal flexural deformation due to the activity of the Rules Viaduct Landside (see [65] as an example). Notice the slight correlation between periods of acceleration of the viaduct and the landslide (Figure 12). (2) Thermal dilation of the viaduct (see [66] as an example). The correlation between periods of acceleration of the viaduct (i.e., uplifting) with summer and the hottest months would support this theory (Figure 13). In any case, our InSAR data seems to indicate that the southern pile could be affected by a certain kind of instability that must be further investigated and monitored.

The most important result from this study is the delimitation of the El Arrecife Landslide. It has been first mapped in its entire dimensions using our InSAR velocity map. No one mapped a landslide covering all this hillside, although several landslide inventories were made in this area. At first sight, we did not recognise any morphology or feature as an indicator to delimitate a landslide, but the distribution of the displacement points from our InSAR velocity map gave us a different perspective. According to the dimensions and the temporal pattern of the movement, we consider that the potential hazard of the El Arrecife Landslide is high. To date, the landslide movement shows a stationary situation with a constant, very slow, velocity that suggests a ductile deformation of the slope [67], and the changes in the reservoir water level do not appear to influence the landslide's behavior. However, we must not forget that the translational character of this landslide makes it possible that the sliding mass is capable of experiencing a rapid acceleration that would lead to a catastrophic slope failure. Consequently, the slide mass would collapse into the reservoir and then generate an impulse wave, as happened in Vajont [68] and other events documented in Alaska [69] and Norway [70]. The N-323 National Road and the powerlines would be also destroyed by this catastrophic event, which would have significant implications (i.e., road accessibility and power cuts) for the nearby populations. Thus, the El Arrecife Landslide study and monitoring must be continued in order to recognise any possible pre-failure precursor (i.e., critical accelerations), as recent studies have demonstrated the effectiveness of InSAR for such an aim (see [71-73] as examples).

\section{Conclusions}

The application of DInSAR tecniques in a reservoir context makes it possible to successfully detect and monitor possible slope instabilities in such a critical infrastructure. In the case of the Rules Reservoir, the InSAR surface velocity maps allowed us: (1) to check the stability of the Rules Dam and the potential unstable slopes where this structure rests; (2) to contribute to the delimitation of three active landslides-Lorenzo-1, Rules Viaduct and El Arrecife landslides; and (3) to monitor the activity of these landslides. The integration of DInSAR data with classical geomorphological research (i.e., field survey and mapping) helped in the definition and understanding of the kinematics and evolution of the landslides, as well as establishing their triggering factors. Thus, we distinguished that the Lorenzo-1 and Rules Viaduct landslides are of the rotational type, while the El Arrecife has a translational character. Moreover, we observed a retrogressive evolution of the rotational landslides that represents a hazard for both the N-323 National Road and the Rules Viaduct. The displacement time series acquired through the DInSAR analysis shows that the behaviour of the Lorenzo-1 and Rules Viaduct landslides is correlated to the continuous changes in the reservoir water level (i.e., drawdowns and infillings). On the contrary, the time series obtained in the El Arrecife Landslide indicated that it was not affected by water level changes. We also detected slight displacements in the Rules Viaduct of the A-44 highway that crosses a branch of the Rules reservoir. These displacements may have different explanations, but the fact is that the viaduct appears to be suffering a small deformation most probably related to the adjacent landslide.

Understanding all this information was crucial to the preliminary assessment of the potential hazards of the unstable slopes in the Rules Reservoir, regarding the different problematics and 
implications in relation to the safety of the reservoir itself and other infrastructures related to it. Thus, this research points out that Lorenzo-1 and Rules Viaduct landslides imply a hazardous situation for the structural integrity of the N-323 and the Rules Viaduct, respectively. On the other hand, El Arrecife Landslide represents a high potential hazard of sudden slope failure. Nevertheless, to date, there is not enough evidence to create social alarm about this topic. In this sense, DInSAR combined with other monitoring tecniques must be continuously applied to detect any pre-failure precursor and any critical deformation along the Rules Viaduct to avoid irreversible damage and also to contribute to the suitable management of the reservoir.

Author Contributions: Conceptualization, C.R.-C., A.B., J.P.G., O.M., R.M.M. and J.M.A.; methodology, C.R.-C., A.B., J.P.G., O.M., J.V.P.-P. and D.N.; software, A.B., O.M. and J.V.P.-P.; validation, C.R.-C., A.B., J.P.G. and O.M.; formal analysis, C.R.-C. and J.P.G.; investigation, C.R.-C., A.B., J.P.G., O.M., J.V.P.-P., R.M.M., D.N., P.R., A.M., J.L.-V. and J.A.; resources, A.B., O.M., J.V.P.-P., R.M.M. and A.M.; writing-original draft preparation, C.R.-C.; writing-review and editing, C.R.-C., A.B., J.P.G., O.M., J.V.P.-P., R.M.M., D.N., P.R., A.M., J.L.-V. and J.A.; visualization, C.R.-C. and J.P.G.; supervision, C.R.-C., A.B., J.P.G. and O.M.; project administration, J.P.G. and O.M.; funding acquisition, C.R.-C., J.P.G., O.M., J.V.P.-P. and J.M.A. All authors have read and agreed to the published version of the manuscript.

Funding: A Spanish "Sistema de Garantía Juvenil" research contract, founded by the Junta de Andalucía and the European Social Funds, supported the work of Cristina Reyes-Carmona. Spanish "Ramón y Cajal" grant supported part of the work of Jorge Pedro Galve. This work has been partially funded by the Spanish Ministry of Economy and Competitiveness through the DEMOS project "Deformation monitoring using Sentinel-1 data" (Ref: CGL2017-83704-P) and the LITHOSURF project "Respuesta de la topografía y la red de drenaje a procesos litosféricos y climáticos en el sur de Iberia" (Ref: CGL2015-67130-C2-1-R). This work has been partially developed in the framework of the RISKCOAST project (Ref: SOE3/P4/E0868) funded by the Interreg SUDOE program (3rd call for proposals).

Acknowledgments: We thank the editors and four anonymous reviewers for helpful comments and suggestions that improved the manuscript.

Conflicts of Interest: The authors declare no conflict of interest.

\section{References}

1. Lane, K.S. Stability of reservoir slopes in: Failure and breakage of rock. In Proceedings of the Eight Sysmposium of Rock Mechanics, University of Minnesota, Minneapolis, MN, USA, 15-17 September 1966; Fairhust, C., Ed.; American Rock Mechanics Association: Alexandria, VA, USA, 1966; pp. 321-336.

2. Kiersch, G.A. Vaiont Reservoir disaster. Civ. Eng. 1964, 34, 32-40.

3. Schuster, R.L. Reservoir-induced landslides. Bull. Int. Assoc. Eng. Geol. Bull. l'Assoc. Int. Géologie l'Ingénieur 1979, 20, 8-15. [CrossRef]

4. Jones, F.O.; Embody, D.R.; Peterson, W.L. Landslides along the Columbia River valley, northeastern Washington. U.S. Geol. Survey Prof. Paper 1961, 367, 1-98.

5. Novosad, S.; Barvinek, R.; de la Torre Sabrevilla, M. Estudio de estabilidad del Derrumbe No. 5 en el reservorio de Tablachaca de la Central Hidroelectrica del Mantaro. In Proceedings of the VI Pan-American Soil Mechanics and Foundation Engineering Congress, Lima, Perú, 2-7 December 1979; pp. 331-344.

6. Qi, S.; Yan, F.; Wang, S.; Xu, R. Characteristics, mechanism and development tendency of deformation of Maoping landslide after commission of Geheyan reservoir on the Qingjiang River, Hubei Province, China. Eng. Geol. 2006, 86, 37-51. [CrossRef]

7. Wang, F.W.; Zhang, Y.M.; Huo, Z.T.; Matsumoto, T.; Huang, B.L. The July 14, 2003 Qianjiangping landslide, three gorges reservoir, China. Landslides 2004, 1, 157-162. [CrossRef]

8. Rybář, J. Prediction of slope failures on water reservoi rbanks. Bull. Int. Assoc. Eng. Geol. Bull. L'assoc. Int. Géologie L'ingénieur 1977, 16, 64-67.

9. Spanilá, T.; Horsky, O.; Banach, M. Slides and sliding in the water reservoirs banks. In Landslides: Proceedings of the First European Conference on Landslides; Rybář, J., Stemberk, J., Wagner, P., Eds.; CRC Press: Prague, Czech Republic, 2002; p. 315.

10. Lopez-Marinas, J.M.; Gazta aga, J.M.; Cajete, J. Landslides in the Cortes reservoir during initial filling. In Proceedings of the Transactions of the Nineteenth International Congress on Large Dams, Florence, Italy, 26-30 May 1997; Volume 3, pp. 537-550. 
11. Gutiérrez, F.; Lucha, P.; Galve, J.P. Reconstructing the geochronological evolution of large landslides by means of the trenching technique in the Yesa Reservoir (Spanish Pyrenees). Geomorphology 2010, 124, 124-136. [CrossRef]

12. Millet, R.A.; Lawton, G.M.; Repetto, P.C.; Garga, V.K. Stabilization of Tablachaca Dam landslide. In Stability and Perfomance of Slopes and Embakments; Seed, R.B., Boulanger, R.W., Eds.; American Society of Civil Engineers: Reston, VA, USA, 1992; Volume 2, pp. 1365-1381.

13. Milillo, P.; Perissin, D.; Salzer, J.T.; Lundgren, P.; Lacava, G.; Milillo, G.; Serio, C. Monitoring dam structural health from space: Insights from novel InSAR techniques and multi-parametric modeling applied to the Pertusillo dam Basilicata, Italy. Int. J. Appl. Earth Obs. Geoinf. 2016, 52, 221-229. [CrossRef]

14. Bozzano, F.; Cipriani, I.; Mazzanti, P.; Prestininzi, A. Displacement patterns of a landslide affected by human activities: Insights from ground-based InSAR monitoring. Nat. Hazards 2011, 59, 1377-1396. [CrossRef]

15. Kraus, K. Photogrammetry, Vol.2, Advanced Methods and Applications; Dümmler Verlag: Bonn, Germany, 1997; $466 \mathrm{p}$.

16. Teza, G.; Galgaro, A.; Zaltron, N.; Genevois, R. Terrestrial laser scanner to detect landslide displacement fields: A new approach. Int. J. Remote Sens. 2007, 28, 3425-3446. [CrossRef]

17. Brunner, F.; Zobl, F.; Gassner, G. On the Capability of GPS for Landslide Monitoring. Felsbau 2003, 21, 51-54.

18. Massonnet, D.; Feigl, K.L. Radar interferometry and its application to changes in the earth's surface. Rev. Geophys. 1998, 36, 441-500. [CrossRef]

19. Monserrat, O.; Crosetto, M.; Luzi, G. A review of ground-based SAR interferometry for deformation measurement. Isprs J. Photogramm. Remote Sens. 2014, 93, 40-48. [CrossRef]

20. Barra, A.; Monserrat, O.; Mazzanti, P.; Esposito, C.; Crosetto, M.; Scarascia Mugnozza, G. First insights on the potential of Sentinel-1 for landslides detection. Geomat. Nat. Hazards Risk 2016, 7, 1874-1883. [CrossRef]

21. Catani, F.; Casagli, N.; Ermini, L.; Righini, G.; Menduni, G. Landslide hazard and risk mapping at catchment scale in the Arno River basin. Landslides 2005, 2, 329-342. [CrossRef]

22. Herrera, G.; Davalillo, J.C.; Mulas, J.; Cooksley, G.; Monserrat, O.; Pancioli, V. Mapping and monitoring geomorphological processes in mountainous areas using PSI data: Central Pyrenees case study. Nat. Hazard Earth Syst. Sci. 2009, 9, 1587-1598. [CrossRef]

23. Cigna, F.; Bianchini, S.; Casagli, N. How to assess landslide activity and intensity with Persistent Scatterer Interferometry (PSI): The PSI-based matrix approach. Landslides 2013, 10, 267-283. [CrossRef]

24. Crosetto, M.; Devanthéry, N.; Cuevas-González, M.; Monserrat, O.; Barra, A.; Crippa, B. Deformation monitoring using Sentinel-1 SAR imagery. In Living Planet Symposium; Mico Milano Congressi: Milan, Italy, 2016.

25. Ciampalini, A.; Raspini, F.; Bianchini, S.; Frodella, W.; Bardi, F.; Lagomarsino, D.; Di Traglia, F.; Moretti, S.; Proietti, C.; Pagliara, P.; et al. Remote sensing as tool for development of landslide databases: The case of the Messina Province (Italy) geodatabase. Geomorphology 2015, 249, 103-118. [CrossRef]

26. Rocca, A.; Mazzanti, P.; Bozzano, F.; Perissin, D. Advanced characterization of a landslide-prone area by satellite a-DInSAR. In Engineering Geology for Society and Territory; Lollino, G., Manconi, A., Guzzetti, F., Culshaw, M., Bobrowsky, P.T., Luino, F., Eds.; Springer International Publishing: Cham, Switzerland, 2015; Volume 5, pp. 177-181.

27. Sousa, J.J.; Hlaváčová, I.; Bakoň, M.; Lazecký, M.; Patrício, G.; Guimarães, P.; Ruiz, A.M.; Bastos, L.; Sousa, A.; Bento, R. Potential of Multi-temporal InSAR Techniques for Bridges and Dams Monitoring. Procedia Technol. 2014, 16, 834-841. [CrossRef]

28. Wang, T.; Perissin, D.; Rocca, F.; Liao, M.S. Three Gorges Dam stability monitoring with time-series InSAR image analysis. Sci. China Earth Sci. 2011, 54, 720-732. [CrossRef]

29. Cignetti, M.; Manconi, A.; Manunta, M.; Giordan, D.; De Luca, C.; Allasia, P.; Ardizzone, F. Taking advantage of the esa G-pod service to study ground deformation processes in high mountain areas: A valle d'aosta case study, northern italy. Remote Sens. 2016, 8, 852. [CrossRef]

30. Wang, G.; Xie, M.; Chai, X.; Wang, L.; Dong, C. D-InSAR-based landslide location and monitoring at Wudongde Hydropower Reservoir in China. Environ. Earth Sci. 2013, 69, 2763-2777. [CrossRef]

31. Barra, A.; Solari, L.; Béjar-Pizarro, M.; Monserrat, O.; Bianchini, S.; Herrera, G.; Crosetto, M.; Sarro, R.; González-Alonso, E.; Mateos, R.M.; et al. A methodology to detect and update active deformation areas based on Sentinel-1 SAR images. Remote Sens. 2017, 9, 1002. [CrossRef] 
32. Rucci, A.; Ferretti, A.; Monti Guarnieri, A.; Rocca, F. Sentinel 1 SAR interferometry applications: The outlook for sub millimeter measurements. Remote Sens. Environ. 2012, 120, 156-163. [CrossRef]

33. Tang, P.; Chen, F.; Guo, H.; Tian, B.; Wang, X.; Ishwaran, N. Large-area landslides monitoring using advanced multi-temporal InSAR technique over the giant panda habitat, Sichuan, China. Remote Sens. 2015, 7, 8925-8949. [CrossRef]

34. Pérez, A.N. La presa de Rules. Rev. De Obras Públicas Órgano Prof. De Los Ing. De Caminoscanales Y Puertos 2004, 3441, 131-152.

35. Bergillos, R.J.; Ortega-Sánchez, M. Assessing and mitigating the landscape effects of river damming on the Guadalfeo River delta, southern Spain. Landsc. Urban. Plan. 2017, 165, 117-129. [CrossRef]

36. Vera, J.; Martín-Algarra, A. Cordillera Bética y Baleares. Divisiones mayores y nomenclatura. In Geología de España; Vera, J., Ed.; SGE-IGME: Madrid, Spain, 2004; pp. 347-350.

37. Simancas, J.F. A reappraisal of the Alpine structure of the Alpujárride Complex in the Betic Cordillera: Interplay of shortening and extension in the westernmost Mediterranean. J. Struct. Geol. 2018, 115, 231-242. [CrossRef]

38. Aldaya, F.; Díaz de Federico, A.; García-Dueñas, V.; Martínez-García, E.; Navarro-Vilá, F.; Puga, E. Lanjarón (1042). Geological Map of Spain 1:50000; Geological Survey of Spain (IGME): Madrid, Spain, 1979.

39. Simancas, J.F.; Campos, J. Compresión NNW-SSE tardi a postmetamórfica y extensión subordinada en el Complejo Alpujárride (Dominio de Alborán, Orógeno Bético). Rev. Soc. Geol. España 1993, 6, $23-35$.

40. Galindo-Zaldívar, J.; Jabaloy, J.; Serrano, I.; Morales, J.; González-Lodeiro, F.; Torcal, F. Recent and present-day stresses in the Granada Basin (Betic Cordilleras): Example of a late Miocene-present-day extensional basin in a convergent plate boundary. Tectonics 1999, 18, 686-702.

41. Martínez-Martínez, J.M.; Soto, J.I.; Balanyá, J.C. Orthogonal folding of extensional detachments: Structure and origin of the Sierra Nevada elongated dome (Betics, SE Spain). Tectonics 2002, 21, 1-20. [CrossRef]

42. Sanz de Galdeano, C.; García Tortosa, F.J.; Peláez Montilla, J.A.; Alfaro García, P.; Azañón, J.M.; Galindo Zaldívar, J.; López-Casado, C.; López-Garrido, A.C.; Rodríguez-Fernández, J.; Ruano, P. Main active faults in the Granada and Guadix-Baza Basins (Betic Cordillera). J. Iber. Geol. 2012, 38, 209-223. [CrossRef]

43. Fernández, T.; Brabb, E.; Delgado, F.; Martin-Algarra, A.; Irigaray, C.; Estévez, A.; Chacón-Montero, J. Rasgos geológicos y movimientos de ladera en el sector Ízbor-Vélez Benaudalla de la cuenca del río Guadalfeo (Granada). In Proceedings of the IV Simposio Nacional Sobre Taludes y Laderas Inestables, Granada, Spain, 11-14 November 1997; pp. 795-808.

44. Chacón, J.; Irigaray, T.; Fernández, T. Los movimientos de ladera de la provincia de Granada. In Atlas Riesgos Naturales en la Provincia de Granada, 1st ed.; Ferrer, M., Ed.; Diputación de Granada-Geological Survey of Spain (IGME): Madrid, Spain, 2007; pp. 45-82.

45. Irigaray, C.; Lamas, F.; El Hamdouni, R.; Fernández, T.; Chacón, J. The importance of the precipitation and the susceptibility of the slopes for the triggering of landslides along the roads. Nat. Hazards 2000, 21, 65-81. [CrossRef]

46. Fernández-Motril, R. La A-44 se Traga en Cuatro Años Más de 80 Millones en Parches; Newspaper 'Granada Hoy': Granada, Spain, 2013.

47. Navarrete, M. El Ministro de Fomento Inaugura el Tramo de Autovía Más caro de España; Newspaper 'Ideal': Granada, Spain, May 2009.

48. Fernández-Motril, R. Fomento Invertirá 19 Millones en Reparar un Nuevo Fallo en el Viaducto de Rules; Newspaper ‘Granada Hoy: Granada, Spain, 2013.

49. Fernández-Motril, R. N-323: Una Carretera Abandonada Desde 2009; Newspaper 'Granada Hoy': Granada, Spain, 2013.

50. Fernández-Motril, R. Fomento Terminará Las Obras del Viaducto de Rules Esta Semana; Newspaper ‘Granada Hoy': Granada, Spain, 2015.

51. Lazecky, M.; Authority, E.; Nikolaeva, E.; Bakon, M. Potential of Sentinel-1a for Nation-Wide Routine Updates of Active Landslide Maps. ISPRS Int. Arch. Photogramm. Remote Sens. Spat. Inf. Sci. 2016, XLI-B7, 775-781. [CrossRef]

52. Devanthéry, N.; Crosetto, M.; Monserrat, O.; Cuevas-González, M.; Crippa, B. An approach to persistent scatterer interferometry. Remote Sens. 2014, 6, 6662-6679. [CrossRef]

53. Biescas, E.; Crosetto, M.; Agudo, M.; Monserrat, O.; Crippa, B. Two radar interferometric approaches to monitor slow and fast land deformation. J. Surv. Eng. 2007, 133, 66-71. [CrossRef] 
54. Crosetto, M.; Monserrat, O.; Cuevas, M.; Crippa, B. Spaceborne differential SAR interferometry: Data analysis tools for deformation measurement. Remote Sens. 2011, 3, 305-318. [CrossRef]

55. Solari, L.; Bianchini, S.; Franceschini, R.; Barra, A.; Monserrat, O.; Thuegaz, P.; Bertolo, D.; Crosetto, M.; Catani, F. Satellite interferometric data for landslide intensity evaluation in mountainous regions. Int. J. Appl. Earth. Obs. 2020, 87, 102028. [CrossRef]

56. Arjona, A.; Santoyo, M.A.; Fernández, J.; Monells, D.; Prieto, J.F.; Pallero, J.L.G.; Prieto, E.; Seco, A.; Luzón, F.; Mallorquí, J. On the Applicability of an Advanced Dinsar Technique near Itoiz and Yesa Reservoirs, Navarra, Spain. Fringe 2009 Work. 2010, 2009, 2-7.

57. Di Martire, D.; Iglesias, R.; Monells, D.; Centolanza, G.; Sica, S.; Ramondini, M.; Pagano, L.; Mallorquí, J.J.; Calcaterra, D. Comparison between Differential SAR interferometry and ground measurements data in the displacement monitoring of the earth-dam of Conza della Campania (Italy). Remote Sens. Environ. 2014, 148, 58-69. [CrossRef]

58. Liao, H.J.; Sheng, Q.; Gao, S.H.; Xu, Z.P. Influence of drawdown of reservoir water level on landslide stability. Chin. J. Rock Mech. Eng. 2005, 24, 3454-3458.

59. Macfarlane, D.F. Observations and predictions of the behaviour of large, slow-moving landslides in schist, Clyde Dam reservoir, New Zealand. Eng. Geol. 2009, 109, 5-15. [CrossRef]

60. Záruba, Q.; Fencl, J.; Simek, J.; Eisenstein, Z. Analysis of the Dneboh Landslide. J. Geol. Sci. 1966, 5, 141-160.

61. De Vita, P.; Reichenbach, P.; Bathurst, J.C.; Borga, M.; Crozier, G.M.; Glade, T.; Guzzetti, F.; Hansen, A.; Wasowski, J. Rainfall-triggered landslides: A reference list. Environ. Geol. 1998, 35, 219-233. [CrossRef]

62. Rybář, J.; Stemberk, J.; Wagner, P. Landslides: Proceedings of the First European Conference on Landslides; CRC Press: Prague, Czech Republic, 2002; 748p.

63. Polemio, O.; Petrucci, O. Rainfall as a Landslide Triggering Factor: an overview of recent international research. In Landslides in Research, Theory and Practice: Proceedings of the 8th International Symposium on Landslides; Bromhead, E., Dixon, N., Ibsen, M.-L., Eds.; Thomas Telford: London, UK, 2000; pp. 1219-1226.

64. Turner, A.K.; Schuster, R.L. Landslides: Investigation and Mitigation. Special Report 247; National Academy Press: Washington, DC, USA, 1996; 673p.

65. Salcedo, D.A. Behavior of a landslide prior to inducing a viaduct failure, Caracas-La Guaira highway, Venezuela. Eng. Geol. 2009, 109, 16-30. [CrossRef]

66. Monserrat, O.; Crosetto, M.; Cuevas, M.; Crippa, B. The thermal expansion component of persistent scatterer interferometry observations. IEEE Geosci. Remote Sens. Lett. 2011, 8, 864-868. [CrossRef]

67. Petley, D.N.; Bulmer, M.H.; Murphy, W. Patterns of movement in rotational and translational landslides. Geology 2002, 30, 719-722. [CrossRef]

68. Datei, C. Riproduzione su Modello in Scala 1:500 Della Frana Caduta nel 1959 Entro il Lago-Serbatoio del Maè; Internal report; University of Padova: Padova, Italy, 2012.

69. Fritz, H.M.; Hager, W.H.; Minor, H.E. Lituya bay case: Rockslide impact and wave run-up. Sci. Tsunami Haz. 2001, 1, 3-22.

70. Harbitz, C.B. Model simulations of tsunamis generated by the Storegga slides. Mar. Geol. 1992, 105, 1-21. [CrossRef]

71. Solari, L.; Raspini, F.; Del Soldato, M.; Bianchini, S.; Ciampalini, A.; Ferrigno, F.; Tucci, S.; Casagli, N. Satellite radar data for back-analyzing a landslide event: the Ponzano (Central Italy) case study. Landslides 2018, 15, 773-782. [CrossRef]

72. Dong, J.; Zhang, L.; Li, M.; Yu, Y.; Liao, M.; Gong, J.; Luo, H. Measuring precursory movements of the recent Xinmo landslide in Mao County, China with Sentinel-1 and ALOS-2 PALSAR-2 datasets. Landslides 2018, 15, 135-144. [CrossRef]

73. Intrieri, E.; Raspini, F.; Fumagalli, A.; Lu, P.; Del Conte, S.; Farina, P.; Allievi, J.; Ferretti, A.; Casagli, N. The Maoxian landslide as seen from space: detecting precursors of failure with Sentinel-1 data. Landslides 2018, 15, 123-133. [CrossRef]

(C) 2020 by the authors. Licensee MDPI, Basel, Switzerland. This article is an open access article distributed under the terms and conditions of the Creative Commons Attribution (CC BY) license (http://creativecommons.org/licenses/by/4.0/). 